\title{
Can Power-sharing Foster Peace? Evidence From Northern Ireland
}

\author{
Hannes Mueller and Dominic Rohner \\ Institut d'Analisi Economica (CSIC), Barcelona GSE, MOVE and CEPR; University of \\ Lausanne and CEPR
}

February 9, 2018

Paper presented at the 66th Panel Meeting of Economic Policy in October 2017

\begin{abstract}
In the absence of power-sharing, minority groups in opposition have powerful incentives to substitute the ballot with the bullet. In contrast, when power is shared among all major groups in society, the relative gains of sticking to electoral politics are larger for minority groups. After making the theoretical argument, we provide in the current paper an empirical analysis of the impact of power-sharing at the local level, making use of fine-grained data from Northern Ireland's 26 local district councils over the 1973-2001 period. We find that power-sharing has a sizable and robust conflict-reducing impact.
\end{abstract}

JEL Classification: C26, D72, D74.

Keywords: Conflict, Terrorism, Peace, Power-Sharing, Elections, Northern Ireland.

Acknowledgements: We thank Quentin Gallea for excellent research assistance. We are also grateful to the editor, Andrea Ichino, to the panellists Francesco Drago and Andrea Weber, as well as conference and seminar participants at the Economic Policy Panel in Brussels, the idiap in Martigny, and the University of Lausanne for helpful comments. Hannes Mueller acknowledges financial support from Grant number ECO2015-66883-P, the Ramon y Cajal programme and the Severo Ochoa Programme, and Dominic Rohner is grateful for financial support from the ERC Starting Grant 677595 "Policies for Peace". 


\section{INTRODUCTION}

Political violence between rival fractions is as old as human history. The death toll of rivalling groups settling scores on the battlefield instead of the negotiation table has been particularly heavy in the $20^{\text {th }}$ century. Politically motivated violence has led to two World Wars, several dozen episodes of mass killings of civilians, devastating purges carried out by a series of totalitarian regimes, as well as dozens of recurrent ethnic civil wars. Most recently, the resurgence of terrorism has hit the headlines as major preoccupation. All in all, conflict-related violence has resulted in over 100 million human lives lost in the $20^{\text {th }}$ century alone. Given the striking extent of armed violence, it is not surprising that wars are a major obstacle to growth and development, with roughly two thirds of the world's poorest countries having been held back by conflict in recent decades (one of course has to bear in mind that causality runs both ways - wars make countries poorer and poorer countries are more likely to be dragged into a war) (see the survey article of Rohner, 2016, for the sources of the above computations and Mueller et al., 2017, for a discussion of the economic costs) ${ }^{1}$.

Not only the escalation of conflict between rivalling factions has shaped human history, but also the quest for solutions to avoid fighting has been centuries old. One promising idea reaching far back has been to share power. A powerful illustration of the potential virtues of power-sharing constitutes the Swiss Constitution of 1848. Switzerland, a highly linguistically and religiously polarized country, experienced a civil war in 1847 between the liberal Protestant forces, pushing for the building of a nation-state, and the conservative Catholic militias, wanting to maintain a loose defensive alliance without further integration. The victorious Protestants had the wise idea to put in place a system that in many accounts gives more than proportional blocking power to their defeated rivals. In particular, the new 1848 Constitution established a nation state based on wide-ranging principles of powersharing with a coalition government, proportional election system, federalist decentralisation, bicameralism, and direct democracy. The Catholic cantons (i.e. provinces) rapidly obtained proportional representation in the government and de facto veto power for all major decisions. There has been peace ever since. ${ }^{2}$ While the whole context matters and one has of course to be careful when applying lessons from $19^{\text {th }}$ century Switzerland to today's conflicts, the success of Swiss post-conflict reconstruction still suggests that power sharing could also be part of the solution in many of the current conflicts like Iraq, Libya and South Sudan.

Much anecdotal evidence and journalist accounts suggest a potentially important role for power-sharing to curb conflict, and there is a clear tendency for some ethnically or religiously divided countries to adopt some power-sharing: As shown in the qualitative work of Lijphart (1999), many successful and peaceful ethnically and religiously divided countries chose the so-called "Consensus Model of Democracy" characterized by power-

\footnotetext{
${ }^{1}$ There is also work showing some positive effects of war, e.g. Voigtländer and Voth (2013).

${ }^{2}$ One of course needs to bear in mind that in electoral systems where the government composition does not react strongly to electoral outcomes this may lower the accountability of the government.
} 
sharing and the decentralization of power on all levels. Still, while historical examples tell us that several ethnically and politically divided countries adopted power-sharing and that this correlates with peace and prosperity, this is a long way from showing systematic statistical evidence that the adoption of power-sharing results in a reduction of the risk of conflict. In fact, there is surprisingly little hard, statistical evidence linking power-sharing to peace. As discussed in detail in the literature review below, there indeed only exists very little theoretical and empirical work that links specific political institutions to the onset of conflicts at the micro level.

To address this shortcoming in the existing literature, in this paper we shall study the impact of power-sharing on the risk of conflict. First, we will- to fix ideas-discuss the theoretical rationale for why one should expect power-sharing to foster peace. The argument takes into account the incentives for election losers to leave regular politics and take up arms. The incentives to do so vary widely with the achieved majorities. In a system with one-partygovernment where even a narrow majority provides extensive powers, an ethnic or religious group defeated at the polls may benefit from very little protection and may have strong incentives to leave the realm of constitutional electoral competition for power. On the contrary, in a system with proportional representation and a grand coalition government where electoral winners and losers are both represented in the government, the actual difference in payoffs after winning versus losing an election are very slim, hence the outside option of rebellion is not very attractive. Take again as example the Swiss system, where the seat composition of the Swiss coalition government has always included all major factions of the political landscape and has been extremely slow moving. The greatest stability has been between 1959-2003 where the so-called "magic formula" has attributed a fixed number of seats to all major parties in the seven-minister government with an annually rotating presidency. Thus, in this period, whether a party won the election with a landslide victory or experienced a crushing electoral defeat did not affect at all the government composition. While the stability of such a power-sharing system may be a bit stark, it has the virtue that incentives of electoral losers to leave the realm of parliamentary politics have been reduced to a minimum.

After the discussion of the underlying theory, as a next step, we will use very disaggregated data from Northern Ireland. Using data on the identity of chairmen in district councils we define power-sharing at the local level as a situation where none of the sectarian parties ${ }^{3}$ holds both chairs. We then see whether this local power-sharing has reduced the scope for violence during the past decades. When -after a period of relative calm- sectarian violence between Catholic Republicans and Protestant Unionists (also called Loyalists) exploded in 1969 , the idea to put in place power-sharing agreements across frontlines rapidly arose, and in the 1970s already several local district governments experimented with sharing power between Catholic and Protestant parties. There was an up and down and the frequency of such local power-sharing governments fluctuated considerably across time and space over

\footnotetext{
${ }^{3}$ By "sectarian party" we understand parties clearly linked to the Catholic or Protestant cause, as opposed to non-sectarian parties that attract voters across the board and focus on issues unrelated to the catholic-protestant conflict.
} 
the following decades. While any statistical evidence on the success of these initiatives is lacking, casual observation suggested a positive impact, which paved the way to scale up the sharing of power to the national level, culminating in the famous nationwide "Good Friday Agreement" agreed upon on the 10 April 1998 in Belfast. ${ }^{4}$ The agreement devolved powers back to Northern Ireland with the explicit aim to ensure power-sharing and inclusivity.

In Figure 1 we provide a first look at our measure of violence, fatalities caused by the conflict (described in more detail below). Since the beginning of multi-party talks in June 1996 preparing the ground for the "Good Friday Agreement" and in the aftermath of its signature there has been a noticeable drop in violence, as shown clearly in the Figure. While before 1995 the level of violence fluctuated considerably on a relatively high level, after 1995 it dropped sharply with the exception of one outlier (a bombing on the 15 August 1998 in Omagh, County Tyrone). This negative correlation between devolution, i.e. powersharing, and violence could of course be spurious and driven by all kinds of omitted factors, which calls for an econometric analysis at the local level.

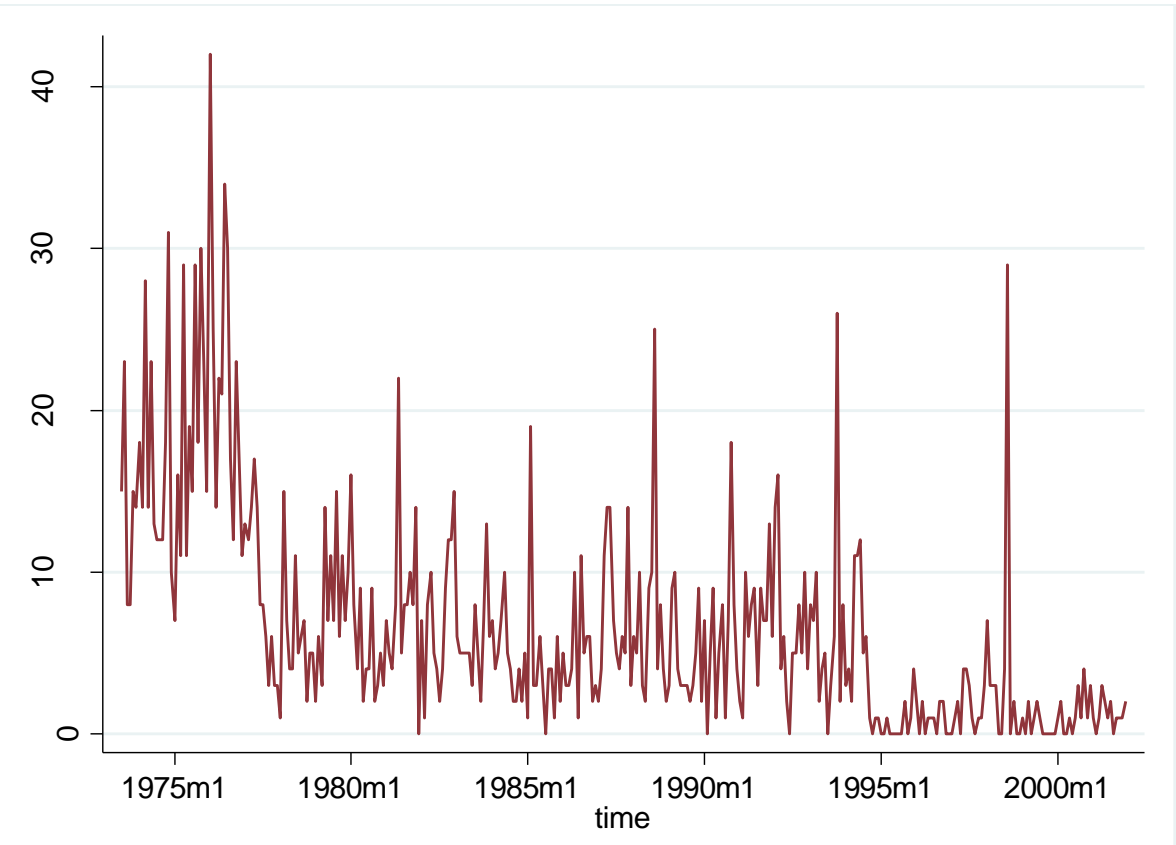

Figure 1. Evolution of fatalities in the Northern Ireland conflict

Thus, to move beyond such aggregate correlations and investigate in depth whether local power-sharing had an actual impact on the number of fatalities is precisely the purpose of the current article. In particular, we shall investigate whether local power-sharing might

${ }^{4}$ For a historical account of the "Good Friday Agreement”, see http://www.bbc.co.uk/history/events/good_friday_agreement. 
have caused a subsequent drop in violence at the local level, despite the often chaotic and controversial attempts at higher levels of government. For this purpose, we have put together a panel dataset of 26 local district councils between 1973 and 2001. While in some of the figures we make use of monthly data, our main unit of observation in the regression analysis is a given year in a given council district, with our explanatory variable of interest being shared power across sectarian lines in the council in this given moment of time. We identify shared power through a novel dataset of the identity of all chairmen and vice chairmen in the councils (in particular, we measure power-sharing as dummy variable taking a value of 1 when the chairman and vice-chairman in a given district are not from the same political block). Our dependent variable that we want to explain is the number of conflictrelated casualties per capita registered in a given district council and year. While we start by using simple regressions to establish the stylized facts, we shall swiftly move to a more advanced econometric analysis where we take into account the concern that there may be omitted, confounding factors that affect both the appeal of power-sharing and the reduction in violence. The presence of open-minded and consensual party leaders in a given district could, for example, make power-sharing more likely and could at the same time ease sectarian tensions, leading to a drop in fatalities in this district.

As described below, we shall address this concern by exploiting an identification strategy based on random variation close to the electoral majority threshold. In particular, we will compare situations where sectarian parties barely achieve the absolute majority (hence reducing strongly the incentives for forming a "grand coalition") with situations that are exante very comparable but where sectarian parties narrowly miss the absolute majority, making it much more appealing to engage in power-sharing (with the alternative being a large potential for political blockade). After establishing these main results of the paper we shall provide a series of robustness checks, before assessing what demographic factors reduce or magnify the impact of power-sharing.

This article is organised as follows: Section 2 provides a review of existing work, showing how the current results contribute to addressing a shortcoming in the existing literature. In Section 3 the main argument is explained in some detail, while Section 4 is devoted to the discussion of the context and the data of Northern Ireland. Section 5 provides the main results and Section 6 the various robustness checks, while Section 7 studies channels of transmission (i.e. what factors reduce or magnify our main impact). Section 8 concludes. Non-technical and time-pressed readers may focus on Sections 3, 4, 5 and 7.

\section{LITERATURE REVIEW}

Political openness and consensual politics have been linked to desirable outcomes such as prosperity and peace in the existing literature. In particular, there is influential recent work linking consensual institutions (Lijphart, 1999) or inclusive institutions (Acemoglu and 
Robinson, 2012) to prosperity. Further, there is some work arguing that democracy in general could reduce the civil war risk by reducing grievances (Gurr, 1971).

Still, most empirical papers find that the effects of democracy are ambiguous, as on the one hand it reduces grievances by enhancing accountability, but on the other hand freedom of speech and assembly facilitate insurgency. Unsurprisingly, there is evidence for an "inverted U-shape", i.e. "anocracies" with intermediate democracy scores fare worst (Hegre et al., 2001; Fearon and Laitin, 2003). Collier and Rohner (2008) find that in poor countries the conflict-fuelling effects of democracy dominate, while in rich countries the peace-promoting channels take the upper hand. There is also cross-country pooled panel evidence that the rule of law, proportional representation and federalism correlate with a lower conflict risk (Easterly, 2001; Reynal-Querol, 2002; Saideman et al, 2002). Moreover, Besley and Persson (2010, 2011) have emphasized the role of institutional constraints for peace by dealing with economic shocks. Recent evidence on ethnic favouritism suggests that political institutions can indeed play an important role in preventing the lopsided distribution of public resources (Hodler and Raschky, 2014; Burgess et al., 2015). However, there are only few contributions linking specific political institutions at the micro level to the risk of violence.

As far as stricto sensu power-sharing is concerned, there is a growing interest in understanding it better. ${ }^{5}$ There are, however, only very few contributions showing that groups included in government show less propensity to engage in insurgency (Cederman and Girardin, 2007; Cederman et al., 2013). Using the same data, Michalopoulos and Papaioannou (2016) show that groups which are split by a national boundary are much more likely to be politically discriminated by the central state. They also argue that political discrimination could form part of the link between partitioned groups and violence. While this work on power-sharing and conflict represents a big leap forward, it has still a series of shortcomings: First of all, a group's power access status is hand-coded by experts (rather than drawn from administrative records). Second, the analysis is restricted to pooled-panel comparisons of different groups, and does not make use of exogenous within-group changes of power access over time. Third, the data is relatively aggregate, i.e. on the country or ethnic group level, making not use of fine-grained spatial information.

There are several gaps in the literature that we shall address in the current paper: After making the theoretical argument of why we expect power-sharing to reduce the scope for conflict, we will provide the first analysis of the power-sharing - conflict nexus that i) uses spatially disaggregate data, ii) uses data which allows us to identify the perpetrators of violence, iii) codes local power-sharing measures from administrative records, iv) runs panel regressions with a large number of fixed effects for 28 years and 26 district councils, and v) makes use of quasi random variation in election outcomes in a subset of politically balanced districts.

\footnotetext{
${ }^{5}$ See Francois, Rainer and Trebbi (2015) for a recent review.
} 


\section{THE THEORETICAL ARGUMENT}

In this section, we shall explain the intuition linking power-sharing to conflict. Picture yourself a country or a local district with two rival ethnic or religious groups. To fix ideas, call them Catholics and Protestants. There are democratic elections, after which a new government is sworn into office. Each of the population groups has the choice of either participating to electoral politics and accepting the verdict of the ballot polls or, alternatively, opt out, take up arms, and try to win (part of) political power by other means, i.e. engage in conflict.

When making the choice of staying in electoral politics or not, the parties anticipate the opportunity cost of leaving the democratic process. In the absence of a power-sharing coalition government the loser of elections may remain almost empty-handed. If ethnic or religious mobilisation is along party lines and a given group is slightly smaller than its opponent, say, has $40 \%$ of the population, in the absence of power-sharing it may end up with only little political say. When access to executive power so crudely deviates from the demographic composition of the population, the group being an empty-handed loser of the ballot has rather powerful incentives to not stay in the realm of constitutional politics, but to enter illegality and engage in violent appropriation. ${ }^{6}$

While in most (developed and developing) former British colonies power-sharing governments are absent (e.g. USA, Zimbabwe), in several multi-ethnic or multi-linguistic European democracies power-sharing agreements take frequently place (e.g. Switzerland, Belgium, Netherlands) and are supported by proportional representation and a tradition of coalition governments. In such a system of shared executive power, a minority group can obtain a share of parliamentary seats and minister posts much closer to its population share, making thus the fact of sticking to electoral politics much more attractive - even for the loser.

Thus, in a nutshell, while with a one-party government the loser may -especially in an ethnically or religiously divided country- have strong incentives to abandon the ballot for the bomb, in a consensual system with power-sharing both the winner and the loser have incentives to stick to electoral politics. This logic applies both to power-sharing at the national as well as at the local level.

Importantly, in practice power-sharing has two elements, proportional representation (PR) and coalition governments. This means that there is a grey-scale of more or less powersharing. At the "no power-sharing" extreme there is majoritarian representation with oneparty governments, in the middle-ground there is PR (which already makes parliamentary seats proportional to group size) but the government is formed by a single party, while on the "full power-sharing" extreme there is PR and a coalition government. Given that since

\footnotetext{
${ }^{6}$ The argument here is therefore akin to the role played by constitutional constraints in Besley and Persson (2011) which prevent rent extraction by the group in power and therefore numb incentives to capture power violently.
} 
1973 local elections in Northern Ireland use a PR system with Single Transferable Vote (STV), ${ }^{7}$ the level of power-sharing observed in given districts and months varies between the middle-ground and full power-sharing.

\section{CONTEXT AND DATA OF NORTHERN IRELAND}

\subsection{The Context}

To study the impact of power-sharing on peace, Northern Ireland is ideally suited. It is a rare example of a developed area experiencing an intense conflict and provides a unique setting that allows us to match detailed conflict events location data with fine-grained census data on the exact number of members from different religious groups.

The Northern part of Ireland, Ulster, has been religiously divided since its conquest by England and the Reformation, taking both place in the 16th century. Since then the Catholic population from Gaelic Irish origin and the Protestant population of English and Scottish settlers have lived "separate lives" characterized by very stable patterns of land holdings and relatively few religiously mixed marriages (Mulholland, 2002; Fernihough, Grada and Walsh, 2015). When the Republic of Ireland achieved independence from Britain in 1919, the six Northern counties of Ireland remained part of the UK. The political divide persisted between the Catholic Nationalists (also called Republicans) who wanted to join the Republic of Ireland and the Protestant Unionists (also called Loyalists) who wanted to remain united with the UK. In 1968 the situation became confrontational when the Civil Rights Movements asked for more rights for Catholic citizens. Some of the initially peaceful demonstrations and marches were met with repression and resulted in fatalities. From August 1969 onwards sectarian violence exploded.

The existing literature by Northern Ireland specialists points out the potential role of gerrymandering and under-representation of Catholics in the political process, and in the administration and police force. The "Orange marches" have also been highlighted as potential factor of escalation. In order to contain the violence, the government put in place a series of measures: Military measures, such as the building of a stronger Royal Ulster Constabulary (RUC), aimed at militarily weakening the Irish Republican Army (IRA). In the same vein, the construction of so-called "peace walls" (i.e. barriers) at sensitive ward borders aimed at containing sectarian violence through segregation. However, also various political initiatives to address grievances were lauched, such as the redistricting of formerly gerrymandered electoral districts, and bottom-up initiatives of decentralized, local powersharing at the level of the 26 regional district councils (which we shall exploit in the current

7 For a description of the electoral
http://cain.ulst.ac.uk/issues/politics/election/electoralsystem.htm.


paper) that culminated in the 1998 "Good Friday agreement" which installed nation-wide large-scale power-sharing. This agreement was followed by a steep decline in violence.

As far as formal political institutions are concerned, from June 1921 to March 1972 Northern Ireland had its own parliament and government within the UK, the "Parliament of Northern Ireland". The system derived from the Government of Ireland Act, 1920, which was designed to set up parliaments in both parts of Ireland. However, according to Carmichael and Knox (2004), Northern Ireland was never envisaged as a shared political entity, and from its foundation in 1921 until the suspension of Stormont in 1972, the Ulster Unionists won a majority at every election and formed the Government of Northern Ireland, making no attempt to share power with Catholics. In the wake of a massive outbreak of violence, the Stormont parliament was suspended and the British Government assumed direct control of Northern Ireland in March 1972.

The local government system in Northern Ireland was established following the Local Government (NI) Act (1972). The act stipulated that every district council was to consist of members which were elected by the local electors and of whom one was to be chairman and another vice-chairman. Under the act, local government districts had three basic roles: an executive role, a representative role and a consultative role. Their executive role involved the provision of a limited range of services, such as environmental health, cleansing, recreation and economic development. The councils' representative role involved nominating local councilors to act as members of various statutory boards. They were consulted by government department officials on the operation of regional services in their area.

According to Knox (1996), the relatively minor role of local government is illustrated by a net expenditure budget of $£ 192 \mathrm{~m}$ from a total public expenditure purse of $£ 8$ billion in the mid-1990s. However, Knox and Carmichael (1998) argue that council chambers became the mechanism for the expression of political opinions often well beyond the ambit of their direct powers. Local authorities were indeed important because they remained the only democratically elected forum in Northern Ireland after the demise of the Northern Ireland Assembly. Secondly, in the absence of any devolved government, councillors were important access points for constituents with concerns about education, health, housing and other mainstream services. Put differently, the role of local councillors assumed an importance beyond the narrow confines of their direct responsibilities and they frequently mediated between constituents and central service providers. Thirdly, councils employed about 9,000 people, which mattered in an economy with high unemployment rates such as Northern Ireland. 


\subsection{The Data}

In what follows, we shall discuss the main variables, data sources and exact proxies used for power-sharing. Our sample contains information on the 26 district councils from 1973 to 2001. For the regression analysis, we aggregate the data at the annual level (while for some part of the analysis we use monthly data). We are able to make use of fine grained data on conflict and religious composition at the district level. In particular, the data on religious composition is from various censuses and is provided by the Northern Ireland Statistics and Research Agency (NISRA). We use the 1971 census to get the number of Catholics and Protestants for each district. As our data excludes respondents who report no or a different confession we get a slight underestimate of population. We combine this data with the census data for 1981 and 1991. In order to get long run averages, we take the long-term average between the three censuses. However, we also run various robustness checks using the interpolated, time-varying data or just the 1971 pre-sample census data.

The data on violence has been originally collected by Sutton (1994), has been updated by the Conflict Archive on the Internet (CAIN), and has been linked to fine-grained geolocalisation in Mueller et al. (2017b). This data only includes killings related directly to the Northern Irish conflict, and no other acts of violence such as non-politically motivated murders. The data is very disaggregated both spatially and in time, and much more precise than most geo-referenced conflict events data for other countries. A very remarkable feature of the data is also that the detailed reports on casualties allow us to identify the religious group affiliation of both the perpetrators and victims of violence, as well as many other individual characteristics. In particular, Sutton (1994) has collected information about the date of death of the victims, the names of the deceased, his or her age, their 'status' in relation to the conflict, which organisation killed them, and a brief description of the circumstances of their death. The source information used includes newspapers, periodicals and books consulted, which are listed in the bibliography of Sutton (1994).

Further, we make use of data on vote shares in district council elections, from the Northern Ireland Statistics and Research Agency (NISRA). In particular, we code variables capturing the vote shares of catholic, protestant and non-sectarian parties. We draw on the elections of 1973, 1977, 1981, 1985, 1989, 1993, 1997 and 2001.

The political debate in Northern Ireland has stressed the importance of the bottom-up power-sharing initiatives by some of the 26 district councils (the main sub-national political units) during the last decades. The UK Freedom of Information act obliges them to answer queries on the exact historical power-sharing agreements at the local level. We have contacted all of these district councils, and they have sent us data on the exact years and party of the council chairman and vice chairman of each council. We use a categorisation of parties as Catholic, Protestant and non-sectarian to construct our main explanatory variables of interest in our paper. 
In particular, the main definition of power-sharing used is as follows: we code a given district in a given month as implementing power-sharing if the mayor (i.e. the chairman of the district council) and the vice-mayor are in parties with different sectarian backgrounds (i.e. Catholic, Protestant, non-sectarian). The reason we rely on this proxy is that indeed the typical way power-sharing was implemented in Northern Ireland in the period studied was that after a formal or informal, implicit agreement, in a situation of power-sharing the main parties involved would rotate the important mayor and vice-mayor positions over the electoral period, with the one party holding this key position in a given year, but offering the vice-mayor position to their partner party, and vice versa in the coming year. In contrast, in a district without power-sharing the party winning elections would typically monopolize all key positions - even if the margin of victory was slim. It is important to notice that in many cases it is difficult to know ex-post up to what extent a given episode we code as powersharing represented a formal or informal agreement, and our data-driven algorithmic approach may -as all algorithmic approaches- both in a few instances wrongly code an episode as power-sharing or miss out on actual power-sharing that took place. ${ }^{8}$

In a nutshell, our method of categorising council districts in this objective, automatic method is a good way to side-step debates regarding whether the intent of each and every sharing of power was indeed the sharing of power. Put differently, while the cost of using an automatic algorithm (as ours) is to possibly increase statistical noise (resulting in potential attenuation bias), it allows to avoid the cognitive biases affecting hand coding (e.g. the hand-coding could be unconsciously affected by prejudices of the coder).

However, we shall also consider two alternative definitions of power-sharing. We first show that the results are robust to a more narrow definition of power-sharing, where non-sectarian parties are discarded and power-sharing is defined as situations with either a Catholic mayor and Protestant vice-mayor or vice versa Protestant mayor and Catholic vice-mayor. Secondly, we will follow the explanations in Knox (1996) who argues that the DUP and Sinn Fein were sceptical with respect to power sharing agreements at the local level and we only keep configurations coded as power-sharing if they do not include these two parties.

\begin{tabular}{lccccc}
\hline Panel A: Full Sample (monthly data) & & & & & \\
\hline Variable & Obs. & Mean & St.De. & Min & Max \\
\hline power sharing & 7293 & 0.3848 & 0.4866 & 0 & 1 \\
Casualties & 7293 & 0.2302 & 0.9741 & 0 & 28 \\
casualties killed by loyalists & 7293 & 0.0664 & 0.4229 & 0 & 9 \\
casual. killed by republicans & 7293 & 0.1351 & 0.5930 & 0 & 12 \\
casual. killed by state forces & 7293 & 0.0186 & 0.1979 & 0 & 9
\end{tabular}

\footnotetext{
${ }^{8}$ As discussed in Knox (1996), the power-sharing agreements in Northern Ireland have implied a great deal of rotation and implicit support of a hung council by the other sectarian bloc. While the incentives for such explicit or implicit power-sharing agreements are shaped by the electoral configuration (and in particular the absence of clear-cut majority), such power-sharing often takes some time to be put in place, with seats being rotated, and parties having to wait until it is their turn to hold the chair / vice-chair positions. This explains why the use of powersharing sometimes also changes in the middle between two elections.
} 


\begin{tabular}{lccccc} 
cath. in district (in 1000s) & 7293 & 35.85 & 19.51 & 6.00 & 115.67 \\
$\begin{array}{l}\text { prot. in district (in 1000s) } \\
\text { share of catholics }\end{array}$ & 7293 & 21.61 & 33.46 & 2.72 & 279.69 \\
& 7293 & 0.685 & 0.189 & 0.195 & 0.908 \\
\hline & & & & & \\
\hline Panel B: Full Sample (yearly data) & & & & & \\
\hline Variable & Obs. & Mean & St.De. & Min & Max \\
\hline power sharing & 619 & 0.3854 & 0.4859 & 0 & 1 \\
casualties & 619 & 2.7124 & 7.6227 & 0 & 117 \\
casualties killed by loyalists & 619 & 0.7819 & 3.2170 & 0 & 52 \\
casual. killed by republicans & 619 & 1.5913 & 4.0828 & 0 & 52 \\
casual. killed by state forces & 619 & 0.2197 & 0.8629 & 0 & 9 \\
cath. in district (in 1000s) & 619 & 35.85 & 19.48 & 6.14 & 115.67 \\
prot. in district (in 1000s) & 619 & 21.57 & 33.50 & 2.72 & 275.77 \\
share of catholics & 619 & 0.685 & 0.189 & 0.199 & 0.908 \\
\hline
\end{tabular}

\begin{tabular}{|c|c|c|c|c|c|}
\hline Variable & Obs. & Mean & St.De. & Min & Max \\
\hline power sharing & 267 & 0.5558 & 0.4969 & 0 & 1 \\
\hline casualties & 267 & 2.4045 & 3.9127 & 0 & 28 \\
\hline casualties killed by loyalists & 267 & 0.4532 & 1.3210 & 0 & 10 \\
\hline casual. killed by republicans & 267 & 1.5618 & 2.5559 & 0 & 15 \\
\hline casual. killed by state forces & 267 & 0.2247 & 0.8146 & 0 & 9 \\
\hline cath. in district (in 1000s) & 267 & 34.05 & 10.53 & 10.91 & 52.24 \\
\hline prot. in district (in 1000s) & 267 & 8.12 & 6.14 & 2.72 & 30.65 \\
\hline share of catholics & 267 & 0.818 & 0.070 & 0.555 & 0.908 \\
\hline
\end{tabular}

Notes: Variable definitions and sources in the main text. Panel C excludes Belfast.

\section{Table 1: Summary Statistics}

Table 1 provides summary statistics of the key variables used in the analysis, at the district level, temporally aggregated at the month (Panel A), resp. annual level (Panel B). In Panel C we present the values of the key variables for the sample of observations around the 50\% vote threshold used later in the 2SLS analysis.

In particular, as shown in the Panels A and B, about 39 percent of all district-months/years experienced power sharing. Over the sample period, there were on average about 2.7 casualties per district and year. Overall this implies almost 1700 deaths in our sample 19732001. In panel C we report summary statistics for a restricted sub-sample of Panel B, which we will explain further below. We run most of our analysis on this sample to ensure better identification of the effect of power sharing. The most striking difference between the two samples of Panel B and Panel C is the number of Protestants which falls dramatically. The reason is that we focus on council districts that were politically balanced, i.e. where Catholic 
and Protestant sectarian parties reached a similar seat share in council elections. This typically happened in areas with Catholics accounting for substantially more than half of the population, the reason being that parts of the Catholic electorate and politicians boycotted the participation to elections organised by a state they considered to be illegitimate. ${ }^{9}$ As is obvious from Panel $\mathrm{C}$, this also means that power-sharing is much more likely in this sample: Roughly 55 percent of all district-years experienced power sharing in the restricted sample.

While Figure 1 in the introduction only depicted violence trends and related this to national politics, we now want to move beyond this simple qualitative nationwide narrative and study the dynamics at the local level. Thus, Figure 2 below displays the correlation between local power-sharing (as defined in more detail above) and violence. As noted before, there are two clear patterns: First, casualties decline over time. There are two major declines in violence. The first at the end of the 1970s and the second in the mid-1990s. Second, the number of council districts which shared power increased. By the end of our sample period more than half of the 26 council districts were sharing power.

It is also noteworthy that power-sharing correlates with lower violence on the timedimension. Especially the later decrease was accompanied by an increase in the number of districts which shared power. Our identification strategy will, however, not exploit these aggregate trends in violence and power-sharing and instead ask whether the violence declined in districts that adopted power sharing after doing so compared to other districts. Here it is important to note that all districts experienced at least one year of power-sharing as defined above.

\footnotetext{
${ }^{9}$ For example, the data presented in McAllister (2004) shows that in the late 1960s, during the 1970s and during much of the 1980s the abstenionism of the Catholics was roughly twice as large as the abstentionism of the Protestants.
} 


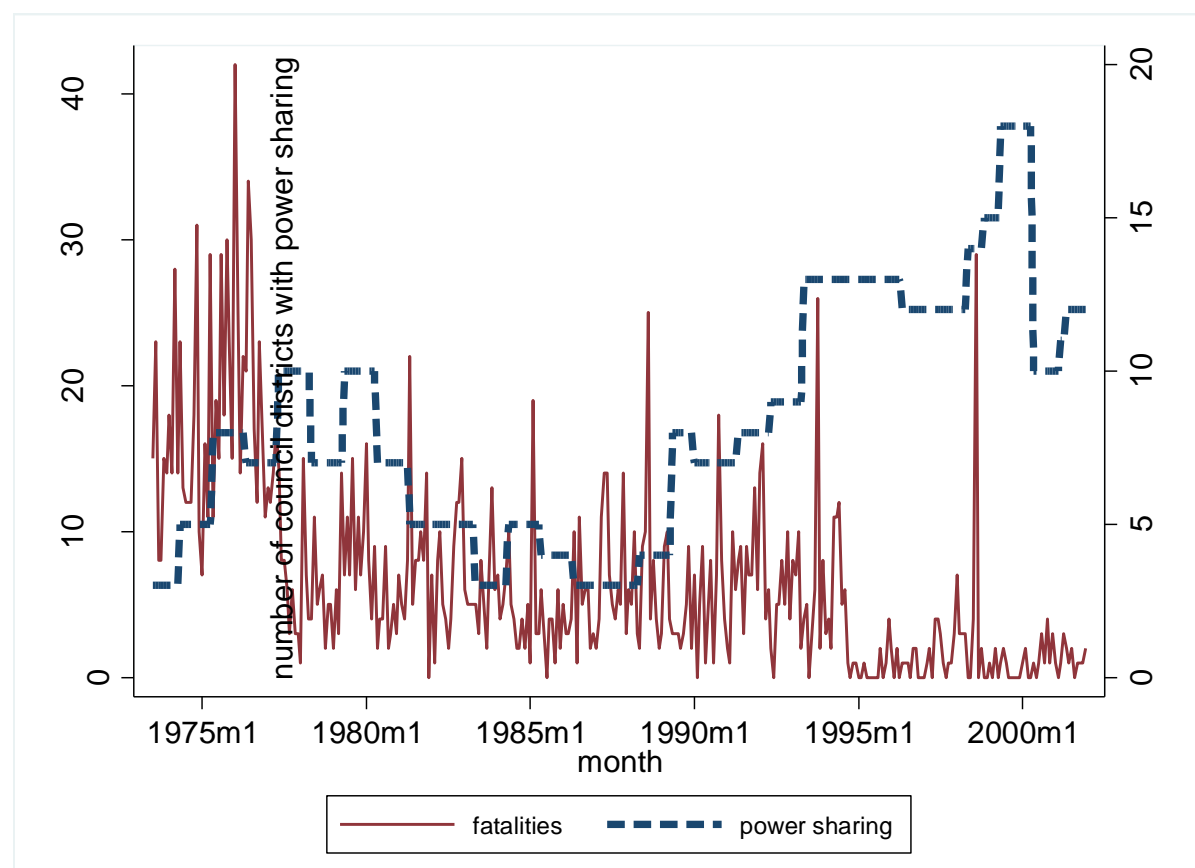

Figure 2. The correlation between fatalities and the extent of local power-sharing

\section{MAIN ECONOMETRIC RESULTS}

Before plunging in the regression analysis, it is important to mention the main empirical challenge: Power-sharing institutions are endogenously selected, which means in plain language that it is not random if a district adopts power-sharing - and districts doing so may be fundamentally different and hence hard to compare to others without power-sharing. This is both a theoretical and an empirical problem. Empirically, places that adopt power-sharing may have other characteristics affecting violence directly. For example, if places with power-sharing were to have more cooperative social norms, then a correlation between less violence and more power-sharing could be spurious, reflecting simply the fact that both variables are correlated to cooperative social norms, i.e. leading to an omitted variable bias. If such confounding factors were at play then a potential correlation between power-sharing and peace would not reveal any causal impact of power-sharing. Put differently, an increase in power-sharing would not result in a reduction in violence, and mistaking correlation for causation could lead to erroneous policy recommendations.

In the regression analysis, we will address the challenges to causal identification by putting in place a series of statistical strategies, which shall be described in detail below. First, we start simple and then refine the econometric tools applied in several steps. 


\subsection{OLS Fixed Effects Results}

As a first step into analysing the effect of power sharing we will exploit the time-variation in power sharing and assess how this correlates with changes in violence at the ward level. In Table 2 we run Ordinary-least squares (OLS) regressions, with the unit of observation being the district-year, and as dependent variable the number of conflict-related fatalities per 1000 inhabitants in a given administrative district-year. Our main explanatory variable is the power-sharing measure as defined above, i.e. a dummy variable taking a value of 1 when power-sharing is present in a given district-year, and zero otherwise. In particular, we run the following specification:

$F_{d t}=\alpha+\beta S_{d t}+\gamma \boldsymbol{X}_{\boldsymbol{d}}+\boldsymbol{\delta} \boldsymbol{Y}_{\boldsymbol{t}}+\boldsymbol{\theta} \boldsymbol{Z}_{d t}+\epsilon_{d t}$

Where d=district, t=year, $F_{d t}=$ fatalities per population, $S_{d t}=$ power-sharing dummy, $\boldsymbol{X}_{\boldsymbol{d}}=$ vector of district fixed effects, $\boldsymbol{Y}_{\boldsymbol{t}}=$ vector of time dummies, $\boldsymbol{Z}_{\boldsymbol{d t}}=$ =vector of further control variables, $\epsilon_{d t}=$ error term.

In column (1) of this table we display the plain raw correlation between power-sharing and fatalities per capita. As expected, we find a negative coefficient that is however not statistically significant. The magnitude of the coefficient in absolute terms is likely to suffer from downward bias, as power-sharing requires some minimum presence of both religious groups, which is also a factor increasing the risk of sectarian violence (put differently, in a religiously homogenous ward the scope for power-sharing and for violence drop alike).

To put in place a first step of refinement of the statistical analysis, a measure to address statistical biases is that from column (2) on all regressions exploit changes in power sharing over time due to the use of 26 district fixed effects, which control for all time-invariant factors in a given local area, e.g. historical industrial or demographic structure. We find in column (2) a negative and statistically significant coefficient for the power-sharing variable. In other words, as power sharing is adopted in a council, this council become significantly less violent.

From column (3) onwards we in addition include 28 year fixed effects, filtering out all global shocks hitting in a given year all of Northern Ireland, e.g. national elections. In a nutshell, all hidden factors that vary at the district level and are constant over time, as well as all global shocks hitting the whole of Northern Ireland are filtered out and cannot bias our estimates. Our findings are robust to the inclusion of these controls for aggregate shocks. Further, in column (4) we include two important control variables related to the political orientation of a given ward: The share of seats won by Catholic, resp. Protestant parties in the last district council election. We will show in the following section that these seat shares were important factors leading to the adoption of power-sharing. Still, the results when controlling for these factors are still very similar and the coefficient of power-sharing remains negative and statistically significant. 
In columns (5) and (6) we exploit as robustness check the fact that we have monthly data. In these regressions, we include year/month fixed effects, i.e. we control for monthly changes in violence. We can easily see that also at the district-month level the results are very similar; the size of the coefficients is about a 12 th of the coefficients in columns (3) and (4).

\begin{tabular}{|c|c|c|c|c|c|c|}
\hline & $(1)$ & $(2)$ & (3) & (4) & $(5)$ & $(6)$ \\
\hline VARIABLES & \multicolumn{6}{|c|}{ casualties per capita } \\
\hline power sharing & $\begin{array}{l}-0.00967 \\
(0.00595)\end{array}$ & $\begin{array}{c}-0.0292 * * * \\
(0.00925)\end{array}$ & $\begin{array}{c}-0.0199 * * * \\
(0.00653)\end{array}$ & $\begin{array}{c}-0.0207 * * * \\
(0.00658)\end{array}$ & $\begin{array}{l}-0.0017 * * * \\
(0.000548)\end{array}$ & $\begin{array}{l}-0.0018^{* * *} \\
(0.000551)\end{array}$ \\
\hline $\begin{array}{l}\text { seat share of catholi } \\
\text { parties }\end{array}$ & & & & $\begin{array}{l}-0.0849 \\
(0.0934)\end{array}$ & & $\begin{array}{l}-0.00705 \\
(0.00805)\end{array}$ \\
\hline $\begin{array}{l}\text { seat share of } \\
\text { protestant parties }\end{array}$ & & & & $\begin{array}{c}-0.109 \\
(0.0827)\end{array}$ & & $\begin{array}{l}-0.00936 \\
(0.00700)\end{array}$ \\
\hline district fixed effects & no & yes & yes & yes & yes & yes \\
\hline $\begin{array}{l}\text { year fixed effects } \\
\text { month/year fixed }\end{array}$ & no & no & yes & yes & no & no \\
\hline effects & no & no & no & no & yes & yes \\
\hline observations & 619 & 619 & 619 & 619 & 7,293 & 7,293 \\
\hline R-squared & 0.004 & 0.034 & 0.212 & 0.217 & 0.076 & 0.077 \\
\hline number of districts & 26 & 26 & 26 & 26 & 26 & 26 \\
\hline
\end{tabular}

Notes: Robust standard errors in parentheses. ${ }^{* * *} p<0.01,{ }^{* *} p<0.05, * p<0.1$. Casualties per capita are casualties per 1000 population. Years in columns (1) to (4) are matched to the electoral cycle which begins in May and ends in April the following year. Columns (5) and (6) use monthly data.

\section{Table 2: OLS regressions with Fixed Effects}

If interpreted as a causal effect, the coefficients in columns (3) to (6) would imply that the adoption of a power sharing agreement at the district level reduced violence by 0.02 deaths per 1000 population and year.

However, controlling for district and time fixed effects is not enough to fully rule out omitted variable bias. For example, what could still be a concern with the regressions run in Table 2 is the worry that there may be shocks or trends at the local level driving both the adoption of power-sharing and increasing peace. Take, for example, a local economic slowdown affecting at the same time election results and opportunity costs of engaging in violence.

One first way to rule out that local political trends drive our results is to look at the variation in violence before and after the election month bringing changes in power sharing. Figure 3 
below displays in one figure both the effect of a start and an end of power-sharing, controlling for district fixed effects and time fixed effects. Left of the 0 are ordered observations before the start of power-sharing or after its end, while to the right of the 0 are depicted observations taking place after power-sharing has started or before power-sharing has ended (e.g. a number of, say, 5 on the horizontal scale displays casualty averages for observations that are 5 months after the beginning of power-sharing or 5 months before its end). The black solid line represents the average casualties per head compared to the average and the two dashed line correspond to the $95 \%$ confidence intervals. The straight red lines show the average levels to the left and right of 0 .

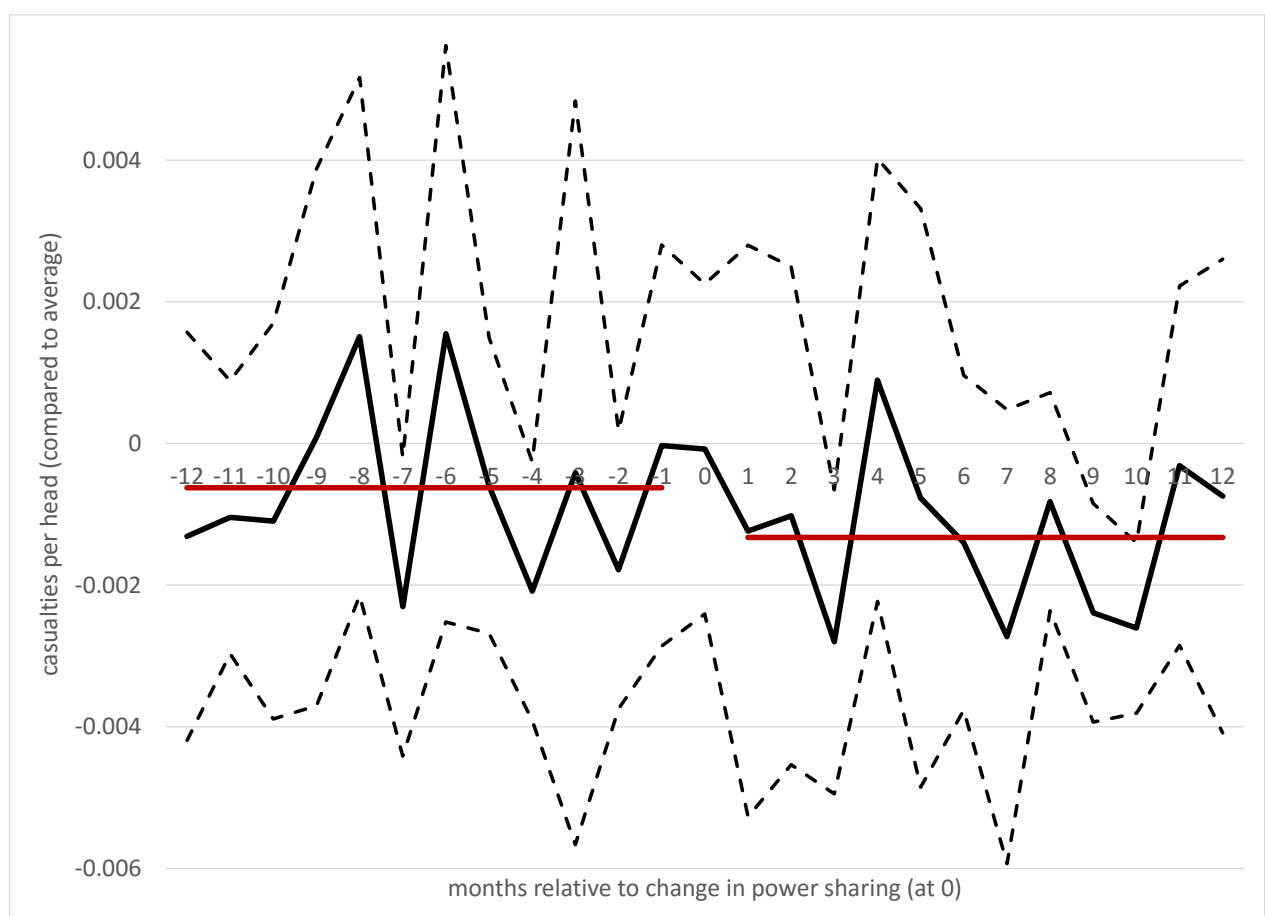

Note: The black solid line corresponds to the coefficients and the dashed lines to the 95 percent confidence interval. The horizontal red lines depict the averages to the left and right of zero. The negative numbers on the left of 0 on the $\mathrm{x}$-axis correspond to the months before the start of the power-sharing or the months after the end of power-sharing. For example, the coefficient of "-2" is the average of casualties in all instances 2 months before the power-sharing start or 2 months after the power-sharing end. Analogously, the positive numbers to the right of 0 correspond to the months after the beginning of power-sharing or the months before the end of power-sharing.

\section{Figure 3. Fatalities in the 12 months around changes to power sharing}

The figure shows that indeed violence tends to be lower in the months following the beginning of a power-sharing agreement as compared to the months before, and also tends to be reduced before the end of power-sharing as opposed to after the power-sharing ended. Crucially, there is no discernible pre-trend in violence or a clear post-trend. Instead, violence, albeit volatile, seems to take on a new average after power sharing is adopted but does not fall before. This allows us to address concerns that long term trends may be 
responsible for both the adoption of power sharing and the fall in violence. Similarly, we find that once power-sharing is removed, the peace-building effects are not persistent but that violence surges again. Again, there is no discernible trend in violence before the end of power sharing. This also suggests that it is unlikely that violence was systematically used to bring down local power sharing. ${ }^{10}$

\subsection{Instrument Results}

To take a further refinement step in our identification strategy we will now instrument the existence of power-sharing in a given year and district with whether any sectarian block, Catholic or Protestant, has managed to win the absolute majority. We expect power-sharing to be more likely when none of the two blocks has an absolute majority.

Districts with clear-cut majorities for one party may differ in various dimensions from districts lacking such an absolute majority. In order to avoid "comparing apples with pears", we shall restrict the analysis to districts where the protestant parties had, on average, a vote share in the vicinity of 50\%, making it quasi-random whether a given election allows them to gain a majority. In the same vein, we also focus on council districts where the number of independents is relatively small to avoid comparing a ward with, say, $40 \%$ Protestants and $60 \%$ non-sectarian seats with, say, a ward with $40 \%$ Protestant and $60 \%$ Catholic seats, which would arguably be a very different place.

Take a numerical example to illustrate this: Say Catholic parties have on average around 50 percent of the seats, independents 15 percent and Protestants 35 percent. Small, random variations could then decide on whether on a given election day the Catholic parties barely reach or miss an absolute majority allowing them to govern alone. If they barely miss the absolute majority, their incentives are much increased to engage in power-sharing (rather than to have to deal with a hung parliament). In terms of identifying variation, changes in the electoral composition of the district council are likely to be driven by either changes in turnout or by switches between sectarian and non-sectarian parties (as shown by McAllister, 2004 , switches of voters from one sectarian block to another are quite rare).

In line with this example we will define a bandwidth of $\mathrm{x} \%$ as the $\mathrm{x}$ percent deviation from the threshold of 50 percent for Protestant sectarian parties, 50 percent for Catholic sectarian parties and 0 percent for non-sectarian parties. A bandwidth of $10 \%$, for example, puts all cases in our sample in which Protestant sectarian parties had between 40 and 60 percent of the seats while non-sectarian parties had less than 10 percent of the seats. Given the limited number of very religiously mixed districts and the relatively small number of elections, too

\footnotetext{
${ }^{10}$ These results are also confirmed when running a regression including current power-sharing and past power-sharing at the same time as explanatory variables. While current power-sharing significantly reduces casualties, the coefficient of past powersharing is not statistically significant. Further, this pattern —of power-sharing start reducing violence but power-sharing end driving it up again - is also confirmed when constructing two separate figures, one for power-sharing start and one for its end (results available upon request).
} 
small a bandwidth would make us lose too much data and restrict the sample too much. It would also increase the risk that the results are driven by a small number of observations. At the same time, a too large bandwidth would increase the risk of biases from unobserved heterogeneity. In the face of this trade-off, we adopt three different bandwidths, displaying the results for these small $(10 \%)$, intermediate $(15 \%)$ and large $(20 \%)$ bandwidth. It should be stressed that we used the average seat share to define the bandwidth and hence which district councils appear in the data. This ensures that we can look at changes in violence over time in the same council districts when political fortunes swing one or the other way. However, we also run robustness checks using contemporaneous seats instead.

Table 3 displays the result from 2SLS regressions with as second stage a modified version of equation (1) described above, where power-sharing $S_{d t}$ is instrumented with a dummy taking a value of 1 when there is no majority, $R_{d t}$.

In column (1) we start with the relatively large bandwidth of 20 percentage points (i.e. including in the sample wards where the mean vote share of Protestant parties lies between 30 and 70 percent, and where the average vote share of non-sectarian parties is below 20 percent). As mentioned above, we instrument for the power-sharing dummy using as instrument a dummy taking a value of 1 when no sectarian block has reached the absolute majority, and zero otherwise. As shown in Table A1 in Appendix B, the predictive power of no majority on power-sharing is very large: The coefficient of no majority in the first stage is positive and significant at the $1 \%$ level. It indicates that without a majority, the likelihood of a power sharing arrangement goes up by over 30 percent. The F-stat of the first stage is well above the conventional threshold of 10 (with the exception of column 6). This relaxes concerns about a weak instrument problem. 


\begin{tabular}{|c|c|c|c|c|c|c|}
\hline & (1) & $(2)$ & (3) & (4) & (5) & (6) \\
\hline & $\begin{array}{c}\text { districts with a } \\
\text { bandwidth of } 20 \\
\text { percent }\end{array}$ & $\begin{array}{c}\text { districts with a } \\
\text { bandwidth of } 15 \\
\text { percent }\end{array}$ & $\begin{array}{c}\text { districts with a } \\
\text { bandwidth of } 10 \\
\text { percent }\end{array}$ & $\begin{array}{c}\text { districts with a } \\
\text { bandwidth of } 20 \\
\text { percent }\end{array}$ & $\begin{array}{c}\text { districts with a } \\
\text { bandwidth of } 15 \\
\text { percent }\end{array}$ & $\begin{array}{c}\text { districts with a } \\
\text { bandwidth of } 10 \\
\text { percent }\end{array}$ \\
\hline VARIABLES & \multicolumn{6}{|c|}{ casualties per capita } \\
\hline power sharing & $\begin{array}{c}-0.146 * * * \\
(0.0462)\end{array}$ & $\begin{array}{c}-0.144^{* * *} \\
(0.0516)\end{array}$ & $\begin{array}{l}-0.106 * * \\
(0.0454)\end{array}$ & $\begin{array}{c}-0.178 * * * \\
(0.0619)\end{array}$ & $\begin{array}{l}-0.175^{* *} \\
(0.0763)\end{array}$ & $\begin{array}{l}-0.135 * \\
(0.0703)\end{array}$ \\
\hline $\begin{array}{l}\text { seat share of } \\
\text { catholic parties }\end{array}$ & & & & $\begin{array}{l}0.0859 \\
(0.160)\end{array}$ & $\begin{array}{c}0.139 \\
(0.168)\end{array}$ & $\begin{array}{c}0.459 * * \\
(0.211)\end{array}$ \\
\hline parties & & & & $\begin{array}{l}-0.281 \\
(0.188)\end{array}$ & $\begin{array}{l}-0.229 \\
(0.209)\end{array}$ & $\begin{array}{l}0.0265 \\
(0.236)\end{array}$ \\
\hline \multicolumn{7}{|l|}{ district fixed } \\
\hline effects & yes & yes & yes & yes & yes & yes \\
\hline time fixed effects & yes & yes & yes & yes & yes & yes \\
\hline observations & 286 & 267 & 173 & 286 & 267 & 173 \\
\hline R-squared & 0.175 & 0.155 & 0.244 & 0.070 & 0.050 & 0.203 \\
\hline $\begin{array}{l}\text { Notes: Robust star } \\
\text { of } 20 \text { percent" is } d \\
\text { non-sectarian part }\end{array}$ & $\begin{array}{l}\text { d errors in parent } \\
\text { ed by an average } \\
\text { below } 0.2 \text {. Other }\end{array}$ & $\begin{array}{l}\text { es. }{ }^{* * *} p<0.01, * \\
\text { e share for protes } \\
\text { dwidths are defin }\end{array}$ & $\begin{array}{l}0.05, * p<0.1 . \mathrm{De} \\
\text { t parties within a } \\
\text { analogously. }\end{array}$ & $\begin{array}{l}\text { dent variable is } \\
\text { ge } 0.3 \text { to } 0.7 \text { ( } 0.5\end{array}$ & $\begin{array}{l}\text { alties per } 1000 \mathrm{po} \\
\text { to } 0.5+0.2 \text { ) and a }\end{array}$ & $\begin{array}{l}\text { ation. "Bandwidth } \\
\text { jerage share for }\end{array}$ \\
\hline
\end{tabular}

Table 3. Baseline results with 2SLS regressions 
Column (1) of Table 3 displays the coefficient in the second stage of the instrumented power-sharing variable. It has the expected negative sign, and is statistically significant at the $1 \%$ level. The fact that the 2SLS coefficients are larger than the OLS coefficients is by no means surprising: While power-sharing arguably has a conflict reducing effect, it is more often adopted in places at risk -- with a large violence potential and unclear political majorities. This typically leads to a sizable downward bias in OLS estimates. ${ }^{11}$

In column (2) the bandwidth is reduced to 15 percent (i.e. to districts with a Protestant seat share within 15 percentage points of the 50 percent threshold, and with non-sectarian parties having less than $15 \%$ of the seats), while in column (3) the bandwidth is further reduced to the mean Protestant vote share being less than 10 percentage points away from $50 \%$ and independents having on average less than $10 \%$ of the seats. Even with this tighter sample restriction the results are very similar, with the coefficient of interest in the second stage being negative and significant. ${ }^{12}$ Columns (4)-(6) replicate the first three columns, but controlling in addition for the share of seats of Catholics and Protestants. The results are very similar. Reassuringly, not only the coefficient of interest is statistically significant in all columns, but also the magnitude of this coefficient is of similar size throughout. These three columns (4)-(6) are our preferred specifications.

The effects are quantitatively sizeable. The coefficient in, say, column (2) in Table 3 amounts to -0.144 , while the mean number of fatalities per 1000 population and year in the sample underlying this regression is about 0.05 (and the standard deviation is 0.09). This means that when comparing in this subsample a situation of no power sharing with power sharing, fatalities per capita would be increased in the absence of power-sharing by roughly three times the baseline risk. Another way to understand the size of the effect is to calculate how many lives have been saved in the restricted sample from power sharing in the $55 \%$ of district-years where it was in place (compared to having no power-sharing at all). From Table 1 we can calculate this as 888 lives. ${ }^{13}$

Note that given the inclusion of district council fixed effects, our coefficients reflect withindistrict changes in relatively violent districts, while in some districts the baseline risk of violence is very low. So it is the intensive and not the extensive margin driving our large coefficients. The standard deviation of our dependent variable is substantially larger than the mean. This implies that reductions in violence over time can lead to large coefficients.

\footnotetext{
${ }^{11}$ Some part of the different magnitude of the OLS versus 2SLS coefficients can also be explained by the fact that the 2SLS sample contains only politically contested districts, for which the effect may be larger. When running the OLS regression of Table 2, column 4 on the sample of Table 3, column 5 (with 267 observations) we obtain a coefficient of -0.039 (significant at the 1 percent level).

${ }^{12}$ Reducing even further the bandwidth would be difficult, as with for example a bandwidth of $+/-5 \%$ around the threshold we would only be left with 72 observations from only 3 districts - which would be a very small sample, especially in our setting with district fixed effects and annual time dummies. If we still run this regression we continue to find a negative coefficient, yet not statistically significant.

${ }^{13}$ The number of district years is $267 * 0.55$, the average population in the sample is $34+8$ thousand, power-sharing is estimated to save in a district-year 0.144 lives per 1000 inhabitants, so that the estimated lives saved corresponds to $267 * 0.55 *(34+8) *(0.144)=888$.
} 


\section{ROBUSTNESS ANALYSIS}

In this section -which may be skipped by non-technical or time-pressed readers- we shall summarise the main robustness checks. All tables mentioned are in the Appendix.

First, we shall show the results for the OLS reduced form relation between the instrument, "No majority", and casualties per capita. This is displayed in Table A2. "No majority" has the expected negative sign and is statistically significant in 5 out of 6 columns.

The second robustness check is to replicate our baseline Table 3 but using the time-varying interpolated population data instead of long-term averages. This checks whether long-term population changes might drive our results. We find that this is not the case. In fact, the estimated coefficients in Table A3 are almost identical to the ones found in Table 3 . The reason is that we are exploiting year-on-year variation and the effects we find are therefore driven by quite sharp changes in violence as shown in Figure 3.

Similarly, in Table A4 we replicate Table 3 but compute the dependent variable, casualties per capita, using time-invariant population data from the 1971 census. This has the virtue of using population values that reflect best pre-conflict demographics. Further, it is useful to point out that in the raw data the population numbers for the 1971 census are also somewhat more balanced than for the following censuses. The results reported in A4 are very similar to the baseline estimates of Table 3 , both in terms of coefficient magnitude and statistical significance.

Our coding of power-sharing is based purely on the names of council chairmen (mayor) and vice-chairmen, which has the advantage of avoiding making subjective judgments which could bias the results. While our strict following of an automatic coding rule allows us to avoid a series of cognitive biases associated to hand-coding, it has the downside of maybe missing out on some subtleties regarding power-sharing agreements. In particular, in his account on power-sharing in Northern Ireland, Knox (1996) has pointed out that the DUP and Sinn Fein parties took a traditionally sceptical stand to power-sharing. Hence, in Table A5 we only keep configurations coded as power-sharing if they do not include these two parties. The point estimates increase slightly. This is consistent with the claims in Knox (1996).

Table A6 focuses on two further robustness checks. First of all, in columns (1)-(3) it replicates columns (4)-(6) of baseline Table 3, but applying this time a more restrictive definition of power-sharing where non-sectarian parties are discarded and where powersharing only refers to situations with either a Catholic mayor and Protestant vice-mayor or a Protestant mayor and Catholic vice-mayor. Then, in columns (4)-(6) it replicates the columns (4)-(6) of baseline Table 3, but using the current instead of the average seat share for constructing the bandwidth of wards included in the sample. The results are very similar and the variable of interest carries on being statistically significant in all columns. Note also 
that the magnitude of the coefficient (in absolute terms) becomes slightly larger with the more restrictive definition of power-sharing, which is very intuitive, as this focuses on cooperation between Catholics and Protestants even in the absence of non-sectarian parties. A caveat is that in some columns of Table A6 the F-stats are very low, and hence the results of this robustness table need to be interpreted with caution due to a weak instrument problem.

Another alternative definition of bandwidths is implemented for Table A7. In columns (1)(3) the running variable used to construct the bandwidth is the share of catholic votes instead of the share of protestant votes. While this is conceptually similar, this alternative construction of bandwidth leads to a lower sample size, as there are fewer districts fulfilling the criteria of inclusion. The results obtained however are very similar. In columns (4)-(6) we go back to our construction of the running variable for the bandwidth being the protestant vote share but we replace the condition on non-sectarian parties being small by an alternative constraint of the catholic parties vote share being below $50 \%$. The results are again very similar.

Further, Table A8 implements another two robustness checks. In columns (1)-(3) we replicate columns (4)-(6) of baseline Table 3, but restricting the sample to before 1995, as arguably after this date nationwide power-sharing initiatives started to kick in and the general level of violence plummeted. Coefficients are estimated somewhat less precisely with less data but they remain statistically significant and the sign and magnitude from Table 3 continue to hold. Note that this implies that we are not confounding aggregate changes with local power sharing. Further, in columns (4)-(6) of Table A8 we replicate again columns (4)-(6) of baseline Table 3, but this time adding the square term of our control variables. The results are again robust.

In Table A9 we focus on the pre-post election changes. In the columns (1)-(3) we replicate the columns (4)-(6) of Table 3, but include in the sample only the years right before and after elections. This leads to a drop of roughly half of the sample. In columns (4)-(6) we also focus on the pre- and post-election period, but collapse the data into two year periods. This again leads to a large drop in the sample size. While in Table A9 the coefficients are of comparable magnitude as in Table 3 the standard errors are much larger, and statistical significance is lost in some of the specifications. The regressions of Table A9 have to be interpreted with caution, as the drop in observations goes along with a serious weak instrument problem in the first stage (with the F-stat falling in some specifications as low as 3).

Finally, we present further tables with additional control variables. To start with, in Table A10 we show that the results of the baseline Table 3 are robust to controlling for lagged casualties. In Table A11 we focus on demographic variables, showing that our results continue to hold when controlling for the population size of Catholics or for religious 
polarization. ${ }^{14}$ In Table A12 we control for the number of the so called "Orange walks" in a given district and year, ${ }^{15}$ as well as for whether there has been a change in the chairman or vice-chairman in a given district and year (to rule out that it is simply any change and not the start of power-sharing in particular that has pacifying effects). Our results are robust to all these controls.

Last but not least, we have generated a variable that lies between 0 and 1 and captures the share of months in a year in which casualties occur in a given district council. This attenuates concerns about few very violent events driving the results. These results are displayed in Table A13. Both the statistical and political significance of the coefficients stays intact.

\section{CHANNELS}

Given that we want to study changes in power-sharing around the 50 percent vote threshold for Protestant parties, we are naturally limited by the number of observations when slicing the data further.

At first, we shall check whether the identified effect holds across the board for all types of fatalities or whether it is restricted to only a particular type of violence, say, group A attacking group B. For this purpose, we replicate our baseline Table 3, but with as dependent variable only the fatalities killed by loyalist paramilitaries (Table A14), the fatalities killed by republican paramilitaries (Table A15), as well as the fatalities killed by state forces (Table A16). All three tables are contained in the Appendix.

We find that power-sharing reduced the killings committed by any of the protagonists of the Northern Irish "Troubles". While we find strong and statistically significant effects for both loyalist and republican paramilitaries, the effects of power-sharing on killings by state forces are somewhat less large and less precisely estimated. This is despite the fact that state forces were responsible for about the same number of casualties as loyalist paramilitaries in our sample. This is in line with the idea that changes in local political representation were driving down local sectarian violence within the respective communities whereas higherlevel violence between state forces and the IRA would still continue.

In Table 4 we investigate whether there is any evidence that the effect of power-sharing is larger or not for places with a higher share of Catholics. In the first two columns, we run the OLS regressions of Table 2, but interact our power-sharing variable of interest with the share of Catholics in the population. We find a negative and significant coefficient on the interaction term between power-sharing and the share of Catholics in the district. Power-

\footnotetext{
${ }^{14}$ Polarization at the district level is computed by the authors using population sizes from NISRA (as described in Section 4.2) and applying the formula of Reynal-Querol (2002).

${ }^{15}$ We have newly collected this data, from personal communication with the "Grand Orange Lodge".
} 
sharing has a larger conflict-reducing effect where Catholics have a bigger majority in the population. In columns (3)-(6) we focus on our baseline IV specifications of Table 3. Given the complications of instrumenting an interaction term, we choose an alternative way of assessing heterogeneous effects, namely to split the sample between below-median and above-median share of Catholics at the council district level. While the picture emerging from columns (3)-(4) still suggests that the effects are larger with a larger Catholic share in the population, in the columns (5)-(6) we cannot detect any heterogeneous effects. ${ }^{16}$

\footnotetext{
${ }^{16}$ We have also investigated whether the impact of power sharing is larger in a configuration of "Catholic mayor, Protestant vice-mayor" versus "Protestant mayor, Catholic vice-mayor" but have not found statistically significant differences (results available upon request)
} 


\begin{tabular}{|c|c|c|c|c|c|c|}
\hline & (1) & $(2)$ & (3) & (4) & (5) & (6) \\
\hline & \multicolumn{2}{|c|}{ OLS } & \multicolumn{4}{|c|}{ IV } \\
\hline & \multicolumn{2}{|c|}{ whole sample } & $\begin{array}{l}\text { less catholic } \\
\text { council districts }\end{array}$ & $\begin{array}{l}\text { more catholic } \\
\text { council districts }\end{array}$ & $\begin{array}{l}\text { less catholic } \\
\text { council districts }\end{array}$ & $\begin{array}{c}\text { more catholic } \\
\text { council districts }\end{array}$ \\
\hline VARIABLES & \multicolumn{6}{|c|}{ casualties per capita } \\
\hline \multirow[t]{2}{*}{ power sharing } & 0.0296 & 0.0278 & $-0.117 * *$ & $-0.182 * * *$ & $-0.203^{*}$ & $-0.198 * *$ \\
\hline & $(0.0256)$ & $(0.0254)$ & $(0.0540)$ & $(0.0622)$ & $(0.111)$ & $(0.0841)$ \\
\hline \multicolumn{7}{|c|}{$\begin{array}{l}\text { power sharing * share of } \\
\text { catholics in council }\end{array}$} \\
\hline \multirow[t]{2}{*}{ district } & $-0.0724^{*}$ & $-0.0711 *$ & & & & \\
\hline & $(0.0391)$ & $(0.0392)$ & & & & \\
\hline \multicolumn{7}{|l|}{ seat share of catholic } \\
\hline \multirow[t]{2}{*}{ parties } & & -0.0817 & & & 0.341 & 0.0334 \\
\hline & & $(0.0936)$ & & & $(0.344)$ & $(0.221)$ \\
\hline \multicolumn{7}{|c|}{ seat share of protestant } \\
\hline parties & & -0.106 & & & -0.443 & -0.218 \\
\hline district fixed effects & yes & yes & yes & yes & yes & yes \\
\hline time fixed effects & yes & yes & yes & yes & yes & yes \\
\hline observations & 619 & 619 & 145 & 141 & 145 & 141 \\
\hline R-squared & 0.219 & 0.224 & 0.219 & 0.204 & -0.16 & 0.160 \\
\hline \multicolumn{7}{|c|}{$\begin{array}{l}\text { Notes: Robust standard errors in parentheses. }{ }^{* *} p<0.01, * * p<0.05, * p<0.1 \text {. Dependent variable is casualties per } 1000 \text { population. The samples are split in } \\
\text { columns (3) to (6). Council districts with many catholics are council districts with more than } 82 \text { percent of Catholics (median). We use a bandwidth of } 20 \\
\text { percent in columns ( } 3 \text { ) to (6). This is defined by an average seat share for protestant parties within a range } 0.3 \text { to } 0.7(0.5-0.2 \text { to } 0.5+0.2) \text { and an average } \\
\text { share for non-sectarian parties below } 0.2 \text {. }\end{array}$} \\
\hline
\end{tabular}

Table 4. Heterogeneous effects with respect to Catholic share 


\section{CONCLUSIONS}

There are compelling conceptual reasons for why to expect power-sharing to reduce the scope of violence. When each group in society (including minority groups) have a guaranteed access to political power, their incentives are larger to bet on politics rather than weaponry to defend their interests. This is due to the fact that additional rents that can be grabbed when gaining power by force are smaller when the peaceful sharing rule is more favourable for opposition groups.

Unfortunately, measuring empirically the causal impact of power sharing on conflict is hard, as power sharing is favoured by similar factors as is peace (e.g. cooperative social norms and trust make both power-sharing and peace more likely). Thus, basing policy recommendations on simple correlations can result in misleading conclusions.

Northern Ireland constitutes an ideal setting to study the impact of power-sharing, as it is one of the rare conflicts taking place in a developed country with excellent data quality and where there has been large-scaled variation in the use of power-sharing. To surmount the econometric challenges mentioned above we thus focus on Northern Ireland, making use of within-district variation. Concretely, we have put in place an empirical strategy based on a series of fixed effects, instrumental variables and restricting the sample to observations close to the majority threshold. This empirical analysis leads to the conclusion that the presence of power-sharing has indeed a strong and robust violence-reducing effect, and on both types of paramilitary groups (republican and loyalist) involved in the fighting.

While this is already a first step towards causal identification, it is important to recognize the limits of the analysis. First of all, the number of observations close to the $50 \%$ votes threshold is not very large and given that the effect of missing out on a majority on powersharing is fuzzy (rather than sharp), there is not enough mass of observations for running a classical regression-discontinuity design. A second caveat is that while our analysis is telling for situations where both groups are close to reaching a majority, which in the Northern Ireland context means to have a sizeable Catholic share, the findings on the impact of power-sharing cannot be extrapolated to other situations where one groups is demographically and politically dominant, limiting hence the external validity of our results. In the same vein, it is important to bear in mind that Northern Ireland is a relatively rich country without many natural resources and that one should be cautious when wanting to extrapolate the current findings to developing countries with more other risk factors for conflict such as poverty and natural resource wealth. Future research on the impact of power-sharing in various configurations is hence strongly encouraged. 


\section{REFERENCES}

Acemoglu, Daron, and James Robinson, 2012, Why Nations Fail: Origins of Power, Poverty and Prosperity, New York: Crown Publishing.

Besley, Timothy, and Torsten Persson, 2010, "State Capacity, Conflict and Development", Econometrica 78: 1-34.

Besley, Timothy, and Torsten Persson, 2011, "The Logic of Political Violence", Quarterly Journal of Economics 126: 1411-1445.

Burgess, Robin, Remi Jedwab, Edward Miguel, Ameet Morjaria, and Gerard Padro i Miquel, 2015, "The Value of Democracy: Evidence from Road Building in Kenya", American Economic Review 105: 1817-51.

Carmichael, Paul, and Colin Knox, 2004, "Devolution, Governance, and the Peace Process", Terrorism and Political Violence 16: 593-621.

Cederman, Lars Erik and Luc Girardin, 2007, "Beyond Fractionalization: Mapping Ethnicity onto Nationalist Insurgencies", American Political Science Review 101: 173-85.

Cederman, Lars-Erik, Kristian Skrede Gleditsch and Halvard Buhaug, 2013, Inequality, Grievances and Civil War, Cambridge: Cambridge University Press.

Collier, Paul, and Dominic Rohner, 2008, "Democracy, Development, and Conflict", Journal of the European Economic Association 6: 531-40.

Easterly, William, 2001, "Can Institutions Resolve Ethnic Conflict?", Economic Development and Cultural Change 49: 687-706.

Fearon, James and David Laitin, 2003, "Ethnicity, Insurgency, and Civil War", American Political Science Review 97: 75-90.

Fernihough, Alan, Cormac Grada, and Brendan Walsh, 2015, "Intermarriage in a divided society: Ireland a century ago", Explorations in Economic History 56: 1-14.

Francois, Patrick, Illia Rainer and Francesco Trebbi, 2015, "How is Power Shared in Africa?", Econometrica 83: 465-503.

Gurr, 1971, Why men rebel, Princeton NJ: Princeton University Press.

Hegre, Havard, Tanja Ellingsen, Scott Gates and Nils Petter Gleditsch, 2001, "Toward a Democratic Civil Peace? Democracy, Political Change, and Civil War, 1816-1992", American Political Science Review 95: 33-48.

Hodler, Roland and Paul A. Raschky, 2014, "Regional Favoritism", Quarterly Journal of Economics 129: 995-1033.

Knox, Colin, 1996, "Emergence of Power Sharing in Northern Ireland: Lessons from Local Government", Journal of Conflict Studies XVI: No. 1.

Knox, Colin and Paul Carmichael, 1998, "Making Progress in Northern Ireland? Evidence from Recent Elections", Government and Opposition 33: 372-393.

Lijphart, Arend, 1999, Patterns of democracy, New Haven: Yale University.

McAllister, Ian, 2004, “The Armalite and the ballot box: Sinn Fein's electoral strategy in Northern Ireland, Electoral Studies 23: 123-142.

Michalopoulos, Stelios and Elias Papaioannou, 2016, "The long-run effects of the scramble for Africa," American Economic Review 106: 1802-48. 
Mueller, Hannes, Lavinia Piemontese and Augustin Tapsoba, 2017, "Revovery from Conflict: Lessons of Success", World Bank Policy Research Working, WPS 7970.

Mueller, Hannes, Dominic Rohner and David Schönholzer, 2017b, "The Peace Dividend of Distance: Violence as Interaction Across Space", Working Paper, IAE, University of Lausanne and UC Berkeley.

Mulholland, Marc, 2002, The longest war: Northern Ireland's troubled history, Oxford: Oxford University Press.

Reynal-Querol, Marta, 2002, "Ethnicity, Political Systems, and Civil Wars", Journal of Conflict Resolution 46: 29-54.

Rohner, Dominic, 2016, "The Economics of Peace: Can "Swiss" Institutions Do the Job? ", UBS Center Public Paper Nr. 5.

Saideman, Stephen, David Lanoue, Michael Campenni and Samuel Stanton, 2002, "Democratization, Political Institutions, and Ethnic Conflict: A Pooled Time-Series Analysis, 19851998", Comparative Political Studies 35: 103-29.

Sutton, Malcolm, 1994, Bear in Mind these Dead ... An Index of Deaths from the Conflict in Ireland 1969-1993, Belfast: Beyond the Pale Publications.

Voigtländer, Nico, and Hans-Joachim Voth, 2013, "The Three Horsemen of Riches: Plague, War, and Urbanization in Early Modern Europe", Review of Economic Studies 80: 774-811. 
APPENDIX: ADDITIONAL TABLES

This appendix contains below the various appendix tables mentioned above in the main text. 


\begin{tabular}{|c|c|c|c|c|c|c|}
\hline & (1) & (2) & (3) & (4) & (5) & (6) \\
\hline VARIABLES & \multicolumn{6}{|c|}{ power sharing agreement } \\
\hline \\
\hline majority & $\begin{array}{c}0.394 * * * \\
(0.0619)\end{array}$ & $\begin{array}{c}0.371 * * * \\
(0.0635)\end{array}$ & $\begin{array}{c}0.396 * * * \\
(0.0884)\end{array}$ & $\begin{array}{c}0.370 * * * \\
(0.0899)\end{array}$ & $\begin{array}{c}0.350 * * \\
(0.113)\end{array}$ & $\begin{array}{c}0.341 * * * \\
(0.0919)\end{array}$ \\
\hline \multirow[t]{2}{*}{ catholic parties seat share } & & & & 0.152 & 0.375 & -0.577 \\
\hline & & & & $(1.222)$ & $(1.372)$ & $(2.189)$ \\
\hline \multirow[t]{2}{*}{ protestant parties seat share } & & & & -0.535 & -0.421 & -1.075 \\
\hline & & & & $(1.282)$ & $(1.375)$ & $(1.654)$ \\
\hline district fixed effects & Yes & yes & yes & yes & yes & yes \\
\hline time fixed effects & Yes & yes & yes & yes & yes & yes \\
\hline observations & 286 & 267 & 173 & 286 & 267 & 173 \\
\hline R-squared & 0.294 & 0.281 & 0.368 & 0.299 & 0.288 & 0.374 \\
\hline Kleibergen-Paap F-stat & 23.46 & 15.79 & 11.1 & 17.8 & 10.58 & 6.88 \\
\hline Number of wards & 12 & 11 & 7 & 12 & 11 & 7 \\
\hline
\end{tabular}

Notes: ${ }^{* * *} \mathrm{p}<0.01,{ }^{* *} \mathrm{p}<0.05, * \mathrm{p}<0.1$.

Table A1. First stage of Baseline Table 2 


\begin{tabular}{|c|c|c|c|c|c|c|}
\hline & (1) & $(2)$ & (3) & (4) & (5) & (6) \\
\hline & $\begin{array}{c}\text { districts with a } \\
\text { bandwidth of } 20 \\
\text { percent }\end{array}$ & $\begin{array}{c}\text { districts with a } \\
\text { bandwidth of } 15 \\
\text { percent }\end{array}$ & $\begin{array}{c}\text { districts with a } \\
\text { bandwidth of } 10 \\
\text { percent }\end{array}$ & $\begin{array}{c}\text { districts with a } \\
\text { bandwidth of } 20 \\
\text { percent }\end{array}$ & $\begin{array}{c}\text { districts with a } \\
\text { bandwidth of } 15 \\
\text { percent }\end{array}$ & $\begin{array}{c}\text { districts with a } \\
\text { bandwidth of } 10 \\
\text { percent }\end{array}$ \\
\hline VARIABLES & \multicolumn{6}{|c|}{ casualties per capita } \\
\hline $\begin{array}{l}\text { no sectarian party has a } \\
\text { majority }\end{array}$ & $\begin{array}{c}-0.0576 * * * \\
(0.0133)\end{array}$ & $\begin{array}{c}-0.0533^{* * *} \\
(0.0163)\end{array}$ & $\begin{array}{l}-0.0420 * \\
(0.0180)\end{array}$ & $\begin{array}{c}-0.0657 * * * \\
(0.0166)\end{array}$ & $\begin{array}{c}-0.0613^{* *} \\
(0.0202)\end{array}$ & $\begin{array}{l}-0.0461 \\
(0.0240)\end{array}$ \\
\hline seat share of catholic parties & & & & $\begin{array}{l}0.0589 \\
(0.243)\end{array}$ & $\begin{array}{l}0.0737 \\
(0.283)\end{array}$ & $\begin{array}{l}0.537^{*} \\
(0.234)\end{array}$ \\
\hline seat share of protestant parties & & & & $\begin{array}{l}-0.186 \\
(0.186)\end{array}$ & $\begin{array}{l}-0.155 \\
(0.218)\end{array}$ & $\begin{array}{c}0.172 \\
(0.214)\end{array}$ \\
\hline district fixed effects & yes & yes & Yes & yes & yes & yes \\
\hline time fixed effects & yes & yes & Yes & yes & yes & yes \\
\hline observations & 286 & 267 & 173 & 286 & 267 & 173 \\
\hline R-squared & 0.258 & 0.226 & 0.271 & 0.276 & 0.242 & 0.339 \\
\hline
\end{tabular}

Table A2. Reduced form estimates 


\begin{tabular}{|c|c|c|c|c|c|c|}
\hline & $(1)$ & $(2)$ & (3) & (4) & $(5)$ & (6) \\
\hline & $\begin{array}{c}\text { districts with a } \\
\text { bandwidth of } 20 \\
\text { percent }\end{array}$ & $\begin{array}{c}\text { districts with a } \\
\text { bandwidth of } 15 \\
\text { percent }\end{array}$ & $\begin{array}{c}\text { districts with a } \\
\text { bandwidth of } 10 \\
\text { percent }\end{array}$ & $\begin{array}{c}\text { districts with a } \\
\text { bandwidth of } 20 \\
\text { percent }\end{array}$ & $\begin{array}{c}\text { districts with a } \\
\text { bandwidth of } 15 \\
\text { percent }\end{array}$ & $\begin{array}{c}\text { districts with a } \\
\text { bandwidth of } 10 \\
\text { percent }\end{array}$ \\
\hline VARIABLES & \multicolumn{6}{|c|}{ casualties per capita } \\
\hline power sharing & $\begin{array}{c}-0.147 * * * \\
(0.0456)\end{array}$ & $\begin{array}{c}-0.151 * * * \\
(0.0527)\end{array}$ & $\begin{array}{l}-0.113^{* *} \\
(0.0470)\end{array}$ & $\begin{array}{c}-0.175 * * * \\
(0.0607)\end{array}$ & $\begin{array}{l}-0.181 * * \\
(0.0774)\end{array}$ & $\begin{array}{l}-0.142^{*} \\
(0.0727)\end{array}$ \\
\hline $\begin{array}{l}\text { seat share of } \\
\text { catholic parties }\end{array}$ & & & & $\begin{array}{c}0.117 \\
(0.157)\end{array}$ & $\begin{array}{c}0.163 \\
(0.170)\end{array}$ & $\begin{array}{c}0.478 * * \\
(0.217)\end{array}$ \\
\hline $\begin{array}{l}\text { seat share of } \\
\text { protestant } \\
\text { parties }\end{array}$ & & & & $\begin{array}{l}-0.250 \\
(0.185)\end{array}$ & $\begin{array}{l}-0.219 \\
(0.213)\end{array}$ & $\begin{array}{l}0.0364 \\
(0.244)\end{array}$ \\
\hline \multicolumn{7}{|l|}{ district fixed } \\
\hline time fixed effects & Yes & yes & yes & yes & yes & yes \\
\hline observations & 286 & 267 & 173 & 286 & 267 & 173 \\
\hline R-squared & 0.196 & 0.159 & 0.245 & 0.107 & 0.061 & 0.204 \\
\hline $\begin{array}{l}\text { Notes: Robust sta } \\
\text { "Bandwidth of } 20 \\
\text { and an average sh } \\
\text { census years } 1971\end{array}$ & $\begin{array}{l}\text { ard errors in paren } \\
\text { rcent" is defined b } \\
\text { e for non-sectariar } \\
981 \text { and } 1991 \text {. }\end{array}$ & $\begin{array}{l}\text { ses. }{ }^{* * *} \mathrm{p}<0.01,{ }^{*} \\
\mathrm{n} \text { average vote sh} \\
\text { rties below } 0.2 .0\end{array}$ & $\begin{array}{l}<0.05, * p<0.1 . D \\
\text { for sectarian pro } \\
\text { r bandwidths are }\end{array}$ & $\begin{array}{l}\text { endent variable } \\
\text { tant parties with } \\
\text { fined analogous }\end{array}$ & $\begin{array}{l}\text { sualties per } 1000 \\
\text { range } 0.3 \text { to } 0.7 \\
\text { opulation is interp }\end{array}$ & $\begin{array}{l}\text { pulation. } \\
-0.2 \text { to } 0.5+0.2 \text { ) } \\
\text { ated between }\end{array}$ \\
\hline
\end{tabular}

Table A3. Using interpolated time-varying population numbers 


\begin{tabular}{|c|c|c|c|c|c|c|}
\hline & (1) & $(2)$ & (3) & (4) & (5) & (6) \\
\hline & $\begin{array}{c}\text { districts with a } \\
\text { bandwidth of } 20 \\
\text { percent }\end{array}$ & $\begin{array}{c}\text { districts with a } \\
\text { bandwidth of } 15 \\
\text { percent }\end{array}$ & $\begin{array}{c}\text { districts with a } \\
\text { bandwidth of } 10 \\
\text { percent }\end{array}$ & $\begin{array}{c}\text { districts with a } \\
\text { bandwidth of } 20 \\
\text { percent }\end{array}$ & $\begin{array}{c}\text { districts with a } \\
\text { bandwidth of } 15 \\
\text { percent }\end{array}$ & $\begin{array}{c}\text { districts with a } \\
\text { bandwidth of } 10 \\
\text { percent }\end{array}$ \\
\hline VARIABLES & \multicolumn{6}{|c|}{ casualties per capita } \\
\hline power sharing & $\begin{array}{c}-0.140 * * * \\
(0.0467)\end{array}$ & $\begin{array}{c}-0.151^{* * *} \\
(0.0542)\end{array}$ & $\begin{array}{l}-0.110 * * \\
(0.0477)\end{array}$ & $\begin{array}{c}-0.167^{* * *} \\
(0.0619)\end{array}$ & $\begin{array}{l}-0.185^{* *} \\
(0.0803)\end{array}$ & $\begin{array}{l}-0.141^{*} \\
(0.0736)\end{array}$ \\
\hline $\begin{array}{l}\text { seat share of } \\
\text { catholic parties }\end{array}$ & & & & $\begin{array}{c}0.115 \\
(0.159)\end{array}$ & $\begin{array}{c}0.139 \\
(0.178)\end{array}$ & $\begin{array}{c}0.474 * * \\
(0.223)\end{array}$ \\
\hline parties & & & & $\begin{array}{l}-0.248 \\
(0.185)\end{array}$ & $\begin{array}{l}-0.246 \\
(0.220)\end{array}$ & $\begin{array}{l}0.0238 \\
(0.249)\end{array}$ \\
\hline \multicolumn{7}{|l|}{ district fixed } \\
\hline time fixed effects & yes & yes & Yes & yes & yes & yes \\
\hline observations & 286 & 267 & 173 & 286 & 267 & 173 \\
\hline R-squared & 0.194 & 0.153 & 0.229 & 0.117 & 0.045 & 0.189 \\
\hline \multicolumn{7}{|c|}{$\begin{array}{l}\text { Notes: Robust standard errors in parentheses. } * * * p<0.01, * * p<0.05, * p<0.1 \text {. Dependent variable is casualties per } 1000 \text { population. "Bandwidth } \\
\text { of } 20 \text { percent" is defined by an average vote share for sectarian protestant parties within a range } 0.3 \text { to } 0.7(0.5-0.2 \text { to } 0.5+0.2) \text { and an average } \\
\text { share for non-sectarian parties below } 0.2 \text {. Other bandwidths are defined analogously. Per capita measure is calculated using population from the } \\
1971 \text { census. }\end{array}$} \\
\hline
\end{tabular}

Table A4. Using time-invariant population numbers from the 1971 census 


\begin{tabular}{|c|c|c|c|c|c|c|}
\hline & (1) & (2) & (3) & (4) & (5) & (6) \\
\hline & $\begin{array}{c}\text { districts with a } \\
\text { bandwidth of } 20 \\
\text { percent }\end{array}$ & $\begin{array}{c}\text { districts with a } \\
\text { bandwidth of } 15 \\
\text { percent }\end{array}$ & $\begin{array}{c}\text { districts with a } \\
\text { bandwidth of } 10 \\
\text { percent }\end{array}$ & $\begin{array}{c}\text { districts with a } \\
\text { bandwidth of } 20 \\
\text { percent }\end{array}$ & $\begin{array}{c}\text { districts with a } \\
\text { bandwidth of } 15 \\
\text { percent }\end{array}$ & $\begin{array}{c}\text { districts with a } \\
\text { bandwidth of } 10 \\
\text { percent }\end{array}$ \\
\hline VARIABLES & \multicolumn{6}{|c|}{ casualties per capita } \\
\hline power sharing & $\begin{array}{l}-0.151^{* * *} \\
(0.0449)\end{array}$ & $\begin{array}{c}-0.140 * * * \\
(0.0438)\end{array}$ & $\begin{array}{l}-0.123^{* *} \\
(0.0518)\end{array}$ & $\begin{array}{c}-0.178^{* * *} \\
(0.0583)\end{array}$ & $\begin{array}{c}-0.161^{* * *} \\
(0.0590)\end{array}$ & $\begin{array}{l}-0.135^{* *} \\
(0.0646)\end{array}$ \\
\hline $\begin{array}{l}\text { seat share of catholic } \\
\text { parties }\end{array}$ & & & & $\begin{array}{l}-0.0760 \\
(0.174)\end{array}$ & $\begin{array}{l}0.0171 \\
(0.170)\end{array}$ & $\begin{array}{c}0.324 \\
(0.235)\end{array}$ \\
\hline $\begin{array}{l}\text { seat share of } \\
\text { protestant parties }\end{array}$ & & & & $\begin{array}{l}-0.237 \\
(0.168)\end{array}$ & $\begin{array}{l}-0.150 \\
(0.161)\end{array}$ & $\begin{array}{l}0.0756 \\
(0.208)\end{array}$ \\
\hline district fixed effects & yes & yes & Yes & yes & yes & yes \\
\hline time fixed effects & yes & yes & Yes & yes & yes & yes \\
\hline observations & 286 & 267 & 173 & 286 & 267 & 173 \\
\hline R-squared & 0.229 & 0.252 & 0.225 & 0.129 & 0.184 & 0.204 \\
\hline $\begin{array}{l}\text { Notes: Robust standa } \\
20 \text { percent" is definec } \\
\text { sectarian parties belo }\end{array}$ & $\begin{array}{l}\text { ors in parenthese } \\
\text { average vote sh } \\
\text { Other bandwidt }\end{array}$ & $\begin{array}{l}* * p<0.01, * * p<0 \\
\text { for protestant pal } \\
\text { re defined analog }\end{array}$ & $\begin{array}{l}* p<0.1 \text {. Depenc } \\
\text { s within a range } c \\
\text { ly. }\end{array}$ & $\begin{array}{l}\text { variable is casu } \\
0.7(0.5-0.2 \text { to }\end{array}$ & $\begin{array}{l}\text { per } 1000 \text { popula } \\
0.2 \text { ) and an aver }\end{array}$ & $\begin{array}{l}\text { n. "Bandwidth of } \\
\text { share for non- }\end{array}$ \\
\hline
\end{tabular}

Table A5. Alternative definition of power-sharing (excluding DUP and Sinn Fein) 


\begin{tabular}{|c|c|c|c|c|c|c|}
\hline & (1) & $(2)$ & (3) & (4) & (5) & (6) \\
\hline \multirow[t]{2}{*}{ ROBUSTNESS } & \multicolumn{3}{|c|}{ Alternative definition power-sharing } & \multicolumn{3}{|c|}{ Alternative definition bandwidth } \\
\hline & $\begin{array}{c}\text { districts with a } \\
\text { bandwidth of } 20 \\
\text { percent }\end{array}$ & $\begin{array}{c}\text { districts with a } \\
\text { bandwidth of } 15 \\
\text { percent }\end{array}$ & $\begin{array}{c}\text { districts with a } \\
\text { bandwidth of } 10 \\
\text { percent }\end{array}$ & $\begin{array}{c}\text { districts with a } \\
\text { bandwidth of } 20 \\
\text { percent }\end{array}$ & $\begin{array}{c}\text { districts with a } \\
\text { bandwidth of } 15 \\
\text { percent }\end{array}$ & $\begin{array}{c}\text { districts with a } \\
\text { bandwidth of } 10 \\
\text { percent }\end{array}$ \\
\hline VARIABLES & \multicolumn{6}{|c|}{ casualties per capita } \\
\hline power sharing & $\begin{array}{c}-0.260 * * \\
(0.128)\end{array}$ & $\begin{array}{c}-0.212^{* *} \\
(0.106)\end{array}$ & $\begin{array}{l}-0.165^{*} \\
(0.0963)\end{array}$ & $\begin{array}{l}-0.164 * * \\
(0.0637)\end{array}$ & $\begin{array}{l}-0.145^{* *} \\
(0.0698)\end{array}$ & $\begin{array}{l}-0.191 \\
(0.189)\end{array}$ \\
\hline $\begin{array}{l}\text { seat share of } \\
\text { catholic parties }\end{array}$ & $\begin{array}{c}0.457 * * \\
(0.227)\end{array}$ & $\begin{array}{c}0.506 * * \\
(0.206)\end{array}$ & $\begin{array}{c}0.759 * * * \\
(0.210)\end{array}$ & $\begin{array}{l}0.0939 \\
(0.182)\end{array}$ & $\begin{array}{l}0.462 * \\
(0.262)\end{array}$ & $\begin{array}{c}-0.000105 \\
(0.695)\end{array}$ \\
\hline $\begin{array}{l}\text { seat share of } \\
\text { prot. Parties }\end{array}$ & $\begin{array}{c}0.166 \\
(0.230) \\
\end{array}$ & $\begin{array}{c}0.221 \\
(0.201) \\
\end{array}$ & $\begin{array}{l}0.337^{*} \\
(0.199) \\
\end{array}$ & $\begin{array}{l}-0.362 \\
(0.260) \\
\end{array}$ & $\begin{array}{c}-0.00465 \\
(0.387) \\
\end{array}$ & $\begin{array}{c}-0.578 \\
(1.169) \\
\end{array}$ \\
\hline dist. fixed effects & yes & yes & yes & yes & yes & yes \\
\hline time fixed effects & yes & yes & yes & yes & yes & yes \\
\hline observations & 286 & 267 & 173 & 300 & 236 & 162 \\
\hline R-squared & -0.561 & -0.228 & 0.037 & 0.077 & 0.260 & -0.527 \\
\hline \multicolumn{7}{|c|}{$\begin{array}{l}\text { Notes: Robust standard errors in parentheses. } * * * p<0.01, * * p<0.05, * p<0.1 \text {. In columns (1)-(3) the "bandwidth of } 20 \text { percent" is defined by the average } \\
\text { seat share for protestant parties within a range } 0.3 \text { to } 0.7(0.5-0.2 \text { to } 0.5+0.2) \text { and a share for non-sectarian parties below } 0.2 \text {. In columns }(4)-(6) \text { the } \\
\text { "bandwidth of } 20 \text { percent" is defined by the contemporaneous seat share for protestant parties within a range } 0.3 \text { to } 0.7(0.5-0.2 \text { to } 0.5+0.2) \text { and an } \\
\text { average share for non-sectarian parties below } 0.2 \text {. Other bandwidths are defined analogously. Columns (1)-(3) use only sectarian party shares to define } \\
\text { power sharing. }\end{array}$} \\
\hline
\end{tabular}

Table A6. Alternative definitions of power-sharing (only sectarian parties) and bandwidth 


\begin{tabular}{|c|c|c|c|c|c|c|}
\hline & (1) & $(2)$ & (3) & (4) & (5) & (6) \\
\hline \multirow[t]{2}{*}{ ROBUSTNESS } & Alternative defin & bandwidth (catho & unning variable) & Alternative definiti & andwidth (catholi & ties less than $50 \%$ ) \\
\hline & $\begin{array}{c}\text { districts with a } \\
\text { bandwidth of } 20 \\
\text { percent }\end{array}$ & $\begin{array}{c}\text { districts with a } \\
\text { bandwidth of } 15 \\
\text { percent }\end{array}$ & $\begin{array}{c}\text { districts with a } \\
\text { bandwidth of } 10 \\
\text { percent }\end{array}$ & $\begin{array}{c}\text { districts with a } \\
\text { bandwidth of } 20 \\
\text { percent }\end{array}$ & $\begin{array}{c}\text { districts with a } \\
\text { bandwidth of } 15 \\
\text { percent }\end{array}$ & $\begin{array}{l}\text { districts with a } \\
\text { bandwidth of } 10 \\
\text { percent }\end{array}$ \\
\hline VARIABLES & \multicolumn{6}{|c|}{ casualties per capita } \\
\hline power sharing & $\begin{array}{l}-0.153^{* *} \\
(0.0608)\end{array}$ & $\begin{array}{l}-0.173 * * \\
(0.0785)\end{array}$ & $\begin{array}{l}-0.171^{*} \\
(0.0919)\end{array}$ & $\begin{array}{l}-0.115^{* *} \\
(0.0503)\end{array}$ & $\begin{array}{c}-0.122 * * * \\
(0.0472)\end{array}$ & $\begin{array}{c}-0.110 * * * \\
(0.0392)\end{array}$ \\
\hline $\begin{array}{l}\text { seat share of } \\
\text { catholic parties }\end{array}$ & $\begin{array}{c}0.152 \\
(0.166)\end{array}$ & $\begin{array}{c}0.103 \\
(0.205)\end{array}$ & $\begin{array}{l}0.0949 \\
(0.213)\end{array}$ & $\begin{array}{c}0.108 \\
(0.123)\end{array}$ & $\begin{array}{l}0.289 * \\
(0.155)\end{array}$ & $\begin{array}{c}0.286 \\
(0.190)\end{array}$ \\
\hline parties & $\begin{array}{l}-0.105 \\
(0.140)\end{array}$ & $\begin{array}{l}-0.239 \\
(0.237)\end{array}$ & $\begin{array}{l}-0.250 \\
(0.244)\end{array}$ & $\begin{array}{l}-0.0847 \\
(0.116)\end{array}$ & $\begin{array}{l}0.0111 \\
(0.150)\end{array}$ & $\begin{array}{l}-0.140 \\
(0.192)\end{array}$ \\
\hline district fix. effects & yes & yes & yes & yes & yes & Yes \\
\hline time fixed effects & yes & yes & yes & yes & yes & Yes \\
\hline Observations & 261 & 240 & 196 & 250 & 232 & 139 \\
\hline R-squared & 0.150 & 0.088 & -0.042 & 0.373 & 0.372 & 0.461 \\
\hline $\begin{array}{l}\text { Notes: Robust stan } \\
\text { seat share for cath } \\
\text { "bandwidth of } 20 \\
\text { parties below } 0.5 \text {. }\end{array}$ & $\begin{array}{l}\text { d errors in parentl } \\
\text { parties within a ra } \\
\text { ent" is defined by } \\
\text { er bandwidths are }\end{array}$ & $\begin{array}{l}* * * p<0.01, * * p \\
0.3 \text { to } 0.7(0.5-0.2 \\
\text { verage seat share } \\
\text { ned analogously. }\end{array}$ & $\begin{array}{l}05, * p<0.1 \text {. In colu } \\
0.5+0.2 \text { ) and a shar } \\
\text { protestant parties }\end{array}$ & $\begin{array}{l}(1)-(3) \text { the "bandv } \\
r \text { non-sectarian par } \\
\text { hin a range } 0.3 \text { to }\end{array}$ & $\begin{array}{l}\text { of } 20 \text { percent" is } \\
\text { below } 0.2 \text {. In colu } \\
.5-0.2 \text { to } 0.5+0.2\end{array}$ & $\begin{array}{l}\text { ed by the average } \\
4)-(6) \text { the } \\
\text { share for catholic }\end{array}$ \\
\hline
\end{tabular}

Table A7. Alternative definitions bandwidth 


\begin{tabular}{|c|c|c|c|c|c|c|}
\hline & (1) & (2) & (3) & (4) & (5) & (6) \\
\hline \multirow[t]{2}{*}{ ROBUSTNESS } & \multicolumn{3}{|c|}{ Restricted to pre-1995 } & \multicolumn{3}{|c|}{ Additional controls } \\
\hline & $\begin{array}{c}\text { districts with a } \\
\text { bandwidth of } 20 \\
\text { percent }\end{array}$ & $\begin{array}{c}\text { districts with a } \\
\text { bandwidth of } 15 \\
\text { percent }\end{array}$ & $\begin{array}{c}\text { districts with a } \\
\text { bandwidth of } 10 \\
\text { percent }\end{array}$ & $\begin{array}{c}\text { districts with a } \\
\text { bandwidth of } 20 \\
\text { percent }\end{array}$ & $\begin{array}{c}\text { districts with a } \\
\text { bandwidth of } 15 \\
\text { percent }\end{array}$ & $\begin{array}{c}\text { districts with a } \\
\text { bandwidth of } 10 \\
\text { percent }\end{array}$ \\
\hline VARIABLES & \multicolumn{6}{|c|}{ casualties per capita } \\
\hline \multirow[t]{2}{*}{ power sharing } & $-0.202 *$ & $-0.158 *$ & $-0.185^{*}$ & $-0.181 * *$ & $-0.183^{* *}$ & $-0.122 * *$ \\
\hline & $(0.114)$ & $(0.0865)$ & $(0.107)$ & $(0.0749)$ & $(0.0887)$ & (0.0596) \\
\hline \multirow[t]{2}{*}{ seat share of catholic parties } & $0.273^{*}$ & $0.345^{* *}$ & $0.616 * * *$ & 0.319 & $0.785^{*}$ & -0.262 \\
\hline & $(0.152)$ & $(0.137)$ & $(0.234)$ & $(0.352)$ & $(0.410)$ & $(1.243)$ \\
\hline \multirow[t]{2}{*}{ seat share of protestant parties } & -0.193 & -0.0854 & 0.127 & -0.947 & $-1.405^{* *}$ & -0.0630 \\
\hline & (0.193) & $(0.148)$ & $(0.218)$ & $(0.672)$ & $(0.712)$ & $(0.988)$ \\
\hline \multirow[t]{2}{*}{ (seat share of cath. $)^{\wedge} 2$} & & & & -0.279 & -0.739 & 0.865 \\
\hline & & & & $(0.490)$ & $(0.548)$ & $(1.268)$ \\
\hline \multirow[t]{2}{*}{ (seat share of prot.)^2 } & & & & 0.586 & $1.062^{*}$ & 0.0667 \\
\hline & & & & $(0.546)$ & $(0.585)$ & $(1.026)$ \\
\hline district fixed effects & yes & yes & yes & yes & yes & yes \\
\hline time fixed effects & yes & yes & yes & yes & yes & yes \\
\hline observations & 213 & 199 & 129 & 286 & 267 & 173 \\
\hline R-squared & 0.091 & 0.256 & 0.056 & 0.054 & 0.018 & 0.272 \\
\hline \multicolumn{7}{|c|}{$\begin{array}{l}\text { Notes: Robust standard errors in parentheses. }{ }^{* * *} p<0.01,{ }^{* *} p<0.05,{ }^{*} p<0.1 \text {. In columns }(1) \text { to }(3) \text { we restrict the sample to the years before } 1995 \text {. } \\
\text { The "bandwidth of } 20 \text { percent" is defined by a vote share for protestant parties within a range } 0.3 \text { to } 0.7(0.5-0.2 \text { to } 0.5+0.2) \text { and a share for non- } \\
\text { sectarian parties below } 0.2 \text {. Other bandwidths are defined analogously. }\end{array}$} \\
\hline
\end{tabular}

Table A8. Restriction to pre-1995 and additional controls 


\begin{tabular}{|c|c|c|c|c|c|c|}
\hline & (1) & $(2)$ & (3) & (4) & (5) & (6) \\
\hline & $\begin{array}{c}\text { districts with a } \\
\text { bandwidth of } 20 \\
\text { percent }\end{array}$ & $\begin{array}{c}\text { districts with a } \\
\text { bandwidth of } 15 \\
\text { percent }\end{array}$ & $\begin{array}{c}\text { districts with a } \\
\text { bandwidth of } 10 \\
\text { percent }\end{array}$ & $\begin{array}{c}\text { districts with a } \\
\text { bandwidth of } 20 \\
\text { percent }\end{array}$ & $\begin{array}{c}\text { districts with a } \\
\text { bandwidth of } 15 \\
\text { percent }\end{array}$ & $\begin{array}{c}\text { districts with a } \\
\text { bandwidth of } 10 \\
\text { percent }\end{array}$ \\
\hline VARIABLES & \multicolumn{6}{|c|}{ casualties per capita } \\
\hline power sharing & $\begin{array}{c}-0.0895^{* *} \\
(0.0443)\end{array}$ & $\begin{array}{l}-0.0901 \\
(0.0641)\end{array}$ & $\begin{array}{l}-0.0688 \\
(0.0639)\end{array}$ & $\begin{array}{l}-0.215^{* *} \\
(0.0849)\end{array}$ & $\begin{array}{l}-0.239 \\
(0.154)\end{array}$ & $\begin{array}{l}-0.195 \\
(0.158)\end{array}$ \\
\hline $\begin{array}{l}\text { seat share of } \\
\text { catholic parties }\end{array}$ & $\begin{array}{c}0.153 \\
(0.129)\end{array}$ & $\begin{array}{c}0.189 \\
(0.155)\end{array}$ & $\begin{array}{c}0.403 * * \\
(0.184)\end{array}$ & $\begin{array}{l}0.399 * \\
(0.224)\end{array}$ & $\begin{array}{c}0.346 \\
(0.286)\end{array}$ & $\begin{array}{c}0.762 * * \\
(0.326)\end{array}$ \\
\hline parties & $\begin{array}{l}-0.179 \\
(0.176)\end{array}$ & $\begin{array}{l}-0.152 \\
(0.242)\end{array}$ & $\begin{array}{l}0.0527 \\
(0.242)\end{array}$ & $\begin{array}{l}-0.296 \\
(0.263)\end{array}$ & $\begin{array}{l}-0.379 \\
(0.429)\end{array}$ & $\begin{array}{l}0.0177 \\
(0.416)\end{array}$ \\
\hline \multicolumn{7}{|l|}{ district fixed } \\
\hline $\begin{array}{l}\text { effects } \\
\text { time fixed effects }\end{array}$ & $\begin{array}{l}\text { yes } \\
\text { yes }\end{array}$ & $\begin{array}{l}\text { yes } \\
\text { yes }\end{array}$ & $\begin{array}{l}\text { yes } \\
\text { yes }\end{array}$ & $\begin{array}{l}\text { yes } \\
\text { yes }\end{array}$ & $\begin{array}{l}\text { yes } \\
\text { yes }\end{array}$ & $\begin{array}{l}\text { yes } \\
\text { yes }\end{array}$ \\
\hline observations & 149 & 141 & 92 & 156 & 145 & 94 \\
\hline R-squared & 0.411 & 0.380 & 0.359 & 0.421 & 0.244 & 0.289 \\
\hline \multicolumn{7}{|c|}{$\begin{array}{l}\text { Notes: Robust standard errors in parentheses. } * * * p<0.01, * * p<0.05, * p<0.1 \text {. Dependent variable is casualties per } 1000 \text { population. Columns } \\
\text { (1)-(3) use only the years before and after local elections (election years are } 1973,1977, \ldots, 2001) \text {. Columns }(4)-(6) \text { uses the sums in two years } \\
\text { before and after elections. "Bandwidth of } 20 \text { percent" is defined by an average vote share for sectarian protestant parties within a range } 0.3 \text { to } \\
0.7(0.5-0.2 \text { to } 0.5+0.2) \text { and an average share for non-sectarian parties below } 0.2 \text {. Other bandwidths are defined analogously. }\end{array}$} \\
\hline
\end{tabular}

Table A9. Restricting to the pre- and post-election period 


\begin{tabular}{|c|c|c|c|c|c|c|}
\hline & $(1)$ & $(2)$ & (3) & (4) & (5) & (6) \\
\hline & $\begin{array}{c}\text { districts with a } \\
\text { bandwidth of } 20 \\
\text { percent }\end{array}$ & $\begin{array}{c}\text { districts with a } \\
\text { bandwidth of } 15 \\
\text { percent }\end{array}$ & $\begin{array}{c}\text { districts with a } \\
\text { bandwidth of } 10 \\
\text { percent }\end{array}$ & $\begin{array}{c}\text { districts with a } \\
\text { bandwidth of } 20 \\
\text { percent }\end{array}$ & $\begin{array}{c}\text { districts with a } \\
\text { bandwidth of } 15 \\
\text { percent }\end{array}$ & $\begin{array}{c}\text { districts with a } \\
\text { bandwidth of } 10 \\
\text { percent }\end{array}$ \\
\hline VARIABLES & \multicolumn{6}{|c|}{ casualties per capita } \\
\hline power sharing & $\begin{array}{c}-0.144^{* * *} \\
(0.0545)\end{array}$ & $\begin{array}{l}-0.149 * * \\
(0.0621)\end{array}$ & $\begin{array}{l}-0.0995^{*} \\
(0.0518)\end{array}$ & $\begin{array}{l}-0.202 * * \\
(0.0842)\end{array}$ & $\begin{array}{c}-0.219 * * \\
(0.111)\end{array}$ & $\begin{array}{l}-0.167 \\
(0.102)\end{array}$ \\
\hline $\begin{array}{l}\text { lagged casualties } \\
\text { per capita }\end{array}$ & $\begin{array}{l}0.00853 \\
(0.0713)\end{array}$ & $\begin{array}{l}-0.0173 \\
(0.0739)\end{array}$ & $\begin{array}{c}0.0742 \\
(0.0935)\end{array}$ & $\begin{array}{l}-0.0662 \\
(0.0914)\end{array}$ & $\begin{array}{r}-0.0987 \\
(0.107)\end{array}$ & $\begin{array}{r}-0.0690 \\
(0.130)\end{array}$ \\
\hline $\begin{array}{l}\text { seat share of } \\
\text { catholic parties }\end{array}$ & & & & $\begin{array}{l}0.0163 \\
(0.180)\end{array}$ & $\begin{array}{l}0.0701 \\
(0.198)\end{array}$ & $\begin{array}{c}0.319 \\
(0.264)\end{array}$ \\
\hline $\begin{array}{l}\text { seat share of } \\
\text { protestant } \\
\text { parties }\end{array}$ & & & & $\begin{array}{l}-0.378 \\
(0.230)\end{array}$ & $\begin{array}{l}-0.354 \\
(0.273)\end{array}$ & $\begin{array}{l}-0.139 \\
(0.323)\end{array}$ \\
\hline \multicolumn{7}{|l|}{ district fixed } \\
\hline time fixed effects & yes & yes & yes & yes & yes & yes \\
\hline observations & 277 & 259 & 168 & 277 & 259 & 168 \\
\hline R-squared & 0.164 & 0.122 & 0.263 & -0.08 & -0.201 & 0.039 \\
\hline $\begin{array}{l}\text { Notes: Robust star } \\
\text { of } 20 \text { percent" is d } \\
\text { share for non-sect }\end{array}$ & $\begin{array}{l}d \text { errors in parent } \\
\text { ed by an average } \\
n \text { parties below } 0 \text {. }\end{array}$ & $\begin{array}{l}\text { es. }{ }^{* *} p<0.01, * * \\
\text { e share for sectari } \\
\text { ther bandwidths }\end{array}$ & $\begin{array}{l}0.05, * p<0.1 . \mathrm{De} \\
\text { protestant partie } \\
\text { defined analogo }\end{array}$ & $\begin{array}{l}\text { ndent variable is c } \\
\text { ithin a range } 0.3 \mathrm{t}\end{array}$ & $\begin{array}{l}\text { alties per } 1000 \text { po } \\
7(0.5-0.2 \text { to } 0.5+\end{array}$ & $\begin{array}{l}\text { ation. "Bandwidth } \\
\text { and an average }\end{array}$ \\
\hline
\end{tabular}

\section{Table A10. Controlling for lagged violence}




\begin{tabular}{|c|c|c|c|c|c|c|}
\hline & (1) & $(2)$ & (3) & (4) & (5) & (6) \\
\hline & $\begin{array}{c}\text { districts with a } \\
\text { bandwidth of } 20 \\
\text { percent }\end{array}$ & $\begin{array}{c}\text { districts with a } \\
\text { bandwidth of } 15 \\
\text { percent }\end{array}$ & $\begin{array}{c}\text { districts with a } \\
\text { bandwidth of } 10 \\
\text { percent }\end{array}$ & $\begin{array}{c}\text { districts with a } \\
\text { bandwidth of } 20 \\
\text { percent }\end{array}$ & $\begin{array}{c}\text { districts with a } \\
\text { bandwidth of } 15 \\
\text { percent }\end{array}$ & $\begin{array}{c}\text { districts with a } \\
\text { bandwidth of } 10 \\
\text { percent }\end{array}$ \\
\hline VARIABLES & \multicolumn{6}{|c|}{ casualties per capita } \\
\hline \multirow[t]{2}{*}{ power sharing } & $-0.167 * * *$ & $-0.175 * *$ & $-0.135^{*}$ & $-0.158 * *$ & $-0.177 * *$ & $-0.134 *$ \\
\hline & $(0.0554)$ & $(0.0756)$ & $(0.0713)$ & $(0.0671)$ & $(0.0811)$ & $(0.0802)$ \\
\hline \multirow[t]{2}{*}{ pop. share of cath. } & -0.347 & -0.138 & 1.859 & & & \\
\hline & $(0.358)$ & $(0.547)$ & $(1.771)$ & & & \\
\hline \multirow[t]{2}{*}{ polarization } & & & & -0.194 & 0.0732 & 0.0424 \\
\hline & & & & (0.137) & $(0.273)$ & $(0.468)$ \\
\hline \multirow[t]{2}{*}{ seat sh. of cath. par. } & 0.111 & 0.136 & $0.536 * * *$ & 0.165 & 0.125 & $0.454^{* *}$ \\
\hline & $(0.149)$ & $(0.173)$ & $(0.193)$ & $(0.178)$ & (0.199) & $(0.203)$ \\
\hline \multirow[t]{2}{*}{ seat sh. of prot. par. } & -0.252 & -0.233 & 0.0817 & -0.180 & -0.245 & 0.0241 \\
\hline & $(0.173)$ & $(0.217)$ & $(0.214)$ & $(0.213)$ & $(0.246)$ & $(0.227)$ \\
\hline \multirow{3}{*}{$\begin{array}{l}\text { district fixed effects } \\
\text { time fixed effects } \\
\text { observations }\end{array}$} & yes & yes & yes & yes & yes & yes \\
\hline & yes & yes & yes & yes & yes & yes \\
\hline & 286 & 267 & 173 & 286 & 267 & 173 \\
\hline R-squared & 0.120 & 0.051 & 0.214 & 0.165 & 0.043 & 0.210 \\
\hline \multicolumn{7}{|c|}{$\begin{array}{l}\text { Notes: Robust standard errors in parentheses. }{ }^{* *} p<0.01,{ }^{*} p<0.05,{ }^{*} p<0.1 \text {. Dependent variable is casualties per } 1000 \text { population. "Bandwidth of } \\
20 \text { percent" is defined by an average vote share for sectarian protestant parties within a range } 0.3 \text { to } 0.7(0.5-0.2 \text { to } 0.5+0.2) \text { and an average share } \\
\text { for non-sectarian parties below } 0.2 \text {. Other bandwidths are defined analogously. Population shares and polarization are calculated with interpolated } \\
\text { population data using census data from } 1971,1981 \text { and } 1991 \text {. }\end{array}$} \\
\hline
\end{tabular}

Table A11. Robustness to additional demographic controls 


\begin{tabular}{|c|c|c|c|c|c|c|}
\hline & $(1)$ & $(2)$ & (3) & $(4)$ & $(5)$ & (6) \\
\hline & $\begin{array}{c}\text { districts with a } \\
\text { bandwidth of } 20 \\
\text { percent }\end{array}$ & $\begin{array}{c}\text { districts with a } \\
\text { bandwidth of } 15 \\
\text { percent }\end{array}$ & $\begin{array}{c}\text { districts with a } \\
\text { bandwidth of } 10 \\
\text { percent }\end{array}$ & $\begin{array}{c}\text { districts with a } \\
\text { bandwidth of } 20 \\
\text { percent }\end{array}$ & $\begin{array}{c}\text { districts with a } \\
\text { bandwidth of } 15 \\
\text { percent }\end{array}$ & $\begin{array}{c}\text { districts with a } \\
\text { bandwidth of } 10 \\
\text { percent }\end{array}$ \\
\hline VARIABLES & \multicolumn{6}{|c|}{ casualties per capita } \\
\hline \multirow[t]{2}{*}{ power sharing } & $-0.179 * * *$ & $-0.179 * *$ & $-0.139 *$ & $-0.192 * * *$ & $-0.202 * *$ & $-0.164 * *$ \\
\hline & $(0.0620)$ & $(0.0769)$ & $(0.0717)$ & $(0.0675)$ & $(0.0912)$ & $(0.0819)$ \\
\hline \multirow[t]{2}{*}{$\mathrm{nr}$. orange walks } & 0.00565 & 0.00570 & 0.00595 & & & \\
\hline & $(0.00363)$ & $(0.00379)$ & $(0.00597)$ & & & \\
\hline \multirow[t]{2}{*}{ change mayor / vice-mayor } & & & & $0.0263^{*}$ & 0.0263 & 0.0246 \\
\hline & & & & $(0.0155)$ & $(0.0181)$ & $(0.0164)$ \\
\hline \multicolumn{7}{|l|}{ seat share of catholic } \\
\hline \multirow[t]{2}{*}{ parties } & 0.0773 & 0.127 & $0.433 * *$ & 0.0749 & 0.108 & $0.438^{*}$ \\
\hline & $(0.160)$ & $(0.169)$ & $(0.217)$ & $(0.168)$ & $(0.187)$ & $(0.233)$ \\
\hline \multirow[t]{2}{*}{ seat share of prot. parties } & -0.286 & -0.239 & 0.00459 & -0.287 & -0.265 & -0.0103 \\
\hline & $(0.189)$ & $(0.211)$ & $(0.244)$ & $(0.196)$ & $(0.232)$ & $(0.260)$ \\
\hline district fixed effects & yes & yes & yes & yes & yes & yes \\
\hline time fixed effects & yes & yes & yes & yes & yes & yes \\
\hline observations & 286 & 267 & 173 & 286 & 267 & 173 \\
\hline R-squared & 0.069 & 0.038 & 0.195 & 0.012 & -0.075 & 0.082 \\
\hline \multicolumn{7}{|c|}{$\begin{array}{l}\text { Notes: Robust standard errors in parentheses. } * * * p<0.01, * * p<0.05, * p<0.1 \text {. Dependent variable is casualties per } 1000 \text { population. "Bandwidth of } 20 \\
\text { percent" is defined by an average vote share for sectarian protestant parties within a range } 0.3 \text { to } 0.7(0.5-0.2 \text { to } 0.5+0.2) \text { and an average share for non- } \\
\text { sectarian parties below } 0.2 \text {. Other bandwidths are defined analogously. Orange marches are the number of recorded marches by orange orders in the } \\
\text { district and year. Changes in mayor or vice mayor are the total number of changes in the party affiliation of the mayor or vice mayor compared to previous } \\
\text { year. }\end{array}$} \\
\hline
\end{tabular}

Table A12. Robustness to additional political controls 


\begin{tabular}{|c|c|c|c|c|c|c|}
\hline & $(1)$ & $(2)$ & (3) & (4) & (5) & (6) \\
\hline & $\begin{array}{c}\text { districts with a } \\
\text { bandwidth of } 20 \\
\text { percent }\end{array}$ & $\begin{array}{c}\text { districts with a } \\
\text { bandwidth of } 15 \\
\text { percent }\end{array}$ & $\begin{array}{c}\text { districts with a } \\
\text { bandwidth of } 10 \\
\text { percent }\end{array}$ & $\begin{array}{c}\text { districts with a } \\
\text { bandwidth of } 20 \\
\text { percent }\end{array}$ & $\begin{array}{c}\text { districts with a } \\
\text { bandwidth of } 15 \\
\text { percent }\end{array}$ & $\begin{array}{c}\text { districts with a } \\
\text { bandwidth of } 10 \\
\text { percent }\end{array}$ \\
\hline VARIABLES & \multicolumn{6}{|c|}{ share of months in which a district had at least one casualty } \\
\hline power sharing & $\begin{array}{c}-0.312 * * * \\
(0.0929)\end{array}$ & $\begin{array}{c}-0.192 * * \\
(0.0826)\end{array}$ & $\begin{array}{c}-0.166 * * \\
(0.0814)\end{array}$ & $\begin{array}{c}-0.414 * * * \\
(0.128)\end{array}$ & $\begin{array}{c}-0.240 * * \\
(0.118)\end{array}$ & $\begin{array}{c}-0.173 \\
(0.115)\end{array}$ \\
\hline $\begin{array}{l}\text { seat share of } \\
\text { catholic parties }\end{array}$ & & & & $\begin{array}{l}-0.352 \\
(0.348)\end{array}$ & $\begin{array}{c}0.139 \\
(0.272)\end{array}$ & $\begin{array}{c}0.815^{* *} \\
(0.365)\end{array}$ \\
\hline $\begin{array}{l}\text { seat share of } \\
\text { non-sectarian } \\
\text { parties }\end{array}$ & & & & $\begin{array}{c}-0.941 * * \\
(0.441)\end{array}$ & $\begin{array}{c}-0.342 \\
(0.355)\end{array}$ & $\begin{array}{c}0.316 \\
(0.418)\end{array}$ \\
\hline $\begin{array}{l}\text { district fixed } \\
\text { effects }\end{array}$ & yes & yes & yes & Yes & yes & yes \\
\hline time fixed effects & yes & yes & yes & Yes & yes & yes \\
\hline observations & 286 & 267 & 173 & 286 & 267 & 173 \\
\hline R-squared & 0.558 & 0.465 & 0.400 & 0.400 & 0.395 & 0.429 \\
\hline
\end{tabular}

Table A13. Robustness to dependent variable being the share of months in which a district had at least one casualty 


\begin{tabular}{|c|c|c|c|c|c|c|}
\hline & (1) & $(2)$ & (3) & (4) & (5) & (6) \\
\hline & $\begin{array}{c}\text { districts with a } \\
\text { bandwidth of } 20 \\
\text { percent }\end{array}$ & $\begin{array}{c}\text { districts with a } \\
\text { bandwidth of } 15 \\
\text { percent }\end{array}$ & $\begin{array}{c}\text { districts with a } \\
\text { bandwidth of } 10 \\
\text { percent }\end{array}$ & $\begin{array}{c}\text { districts with a } \\
\text { bandwidth of } 20 \\
\text { percent }\end{array}$ & $\begin{array}{c}\text { districts with a } \\
\text { bandwidth of } 15 \\
\text { percent }\end{array}$ & $\begin{array}{c}\text { districts with a } \\
\text { bandwidth of } 10 \\
\text { percent }\end{array}$ \\
\hline VARIABLES & \multicolumn{6}{|c|}{ casualties per capita (killed by loyalist paramilitaries) } \\
\hline power sharing & $\begin{array}{c}-0.0449 * * * \\
(0.0143)\end{array}$ & $\begin{array}{c}-0.0407^{* *} \\
(0.0166)\end{array}$ & $\begin{array}{l}-0.0313 * \\
(0.0174)\end{array}$ & $\begin{array}{c}-0.0590 * * * \\
(0.0187)\end{array}$ & $\begin{array}{c}-0.0562 * * \\
(0.0237)\end{array}$ & $\begin{array}{l}-0.0493 * \\
(0.0252)\end{array}$ \\
\hline $\begin{array}{l}\text { seat share of catholic } \\
\text { parties }\end{array}$ & & & & $\begin{array}{c}0.0315 \\
(0.0587)\end{array}$ & $\begin{array}{c}0.0517 \\
(0.0612)\end{array}$ & $\begin{array}{c}0.0991 \\
(0.0961)\end{array}$ \\
\hline $\begin{array}{l}\text { seat share of } \\
\text { protestant parties }\end{array}$ & & & & $\begin{array}{l}-0.126 * * \\
(0.0634)\end{array}$ & $\begin{array}{c}-0.112 \\
(0.0691)\end{array}$ & $\begin{array}{l}-0.0638 \\
(0.0935)\end{array}$ \\
\hline district fixed effects & yes & yes & yes & yes & yes & yes \\
\hline time fixed effects & yes & yes & yes & yes & yes & yes \\
\hline observations & 286 & 267 & 173 & 286 & 267 & 173 \\
\hline R-squared & 0.180 & 0.129 & 0.180 & 0.069 & 0.002 & 0.077 \\
\hline
\end{tabular}

Table A14. Explaining casualties killed by loyalist paramilitaries 


\begin{tabular}{|c|c|c|c|c|c|c|}
\hline & (1) & $(2)$ & (3) & (4) & (5) & (6) \\
\hline & $\begin{array}{c}\text { districts with a } \\
\text { bandwidth of } 20 \\
\text { percent }\end{array}$ & $\begin{array}{c}\text { districts with a } \\
\text { bandwidth of } 15 \\
\text { percent }\end{array}$ & $\begin{array}{c}\text { districts with a } \\
\text { bandwidth of } 10 \\
\text { percent }\end{array}$ & $\begin{array}{c}\text { districts with a } \\
\text { bandwidth of } 20 \\
\text { percent }\end{array}$ & $\begin{array}{c}\text { districts with a } \\
\text { bandwidth of } 15 \\
\text { percent }\end{array}$ & $\begin{array}{c}\text { districts with a } \\
\text { bandwidth of } 10 \\
\text { percent }\end{array}$ \\
\hline VARIABLES & \multicolumn{6}{|c|}{ casualties per capita (killed by republican paramilitaries) } \\
\hline power sharing & $\begin{array}{c}-0.0606 * * * \\
(0.0227)\end{array}$ & $\begin{array}{c}-0.0677^{* *} \\
(0.0285)\end{array}$ & $\begin{array}{l}-0.0638^{*} \\
(0.0327)\end{array}$ & $\begin{array}{c}-0.0690 * * \\
(0.0285)\end{array}$ & $\begin{array}{l}-0.0727^{*} \\
(0.0387)\end{array}$ & $\begin{array}{l}-0.0775 \\
(0.0495)\end{array}$ \\
\hline $\begin{array}{l}\text { seat share of catholic } \\
\text { parties }\end{array}$ & & & & $\begin{array}{l}0.148 * * \\
(0.0732)\end{array}$ & $\begin{array}{l}0.171 * * \\
(0.0806)\end{array}$ & $\begin{array}{l}0.332 * * \\
(0.139)\end{array}$ \\
\hline $\begin{array}{l}\text { seat share of } \\
\text { protestant parties }\end{array}$ & & & & $\begin{array}{l}-0.0704 \\
(0.0953)\end{array}$ & $\begin{array}{l}-0.0486 \\
(0.112)\end{array}$ & $\begin{array}{l}0.0630 \\
(0.164)\end{array}$ \\
\hline district fixed effects & yes & yes & yes & yes & yes & yes \\
\hline time fixed effects & yes & yes & yes & yes & yes & yes \\
\hline observations & 286 & 267 & 173 & 286 & 267 & 173 \\
\hline R-squared & 0.365 & 0.339 & 0.266 & 0.362 & 0.349 & 0.266 \\
\hline $\begin{array}{l}\text { Notes: Robust standa } \\
\text { groups per } 1000 \text { pop } \\
0.5+0.2 \text { ) and an aver }\end{array}$ & $\begin{array}{l}\text { rs in parenthese } \\
\text { "Bandwidth of } \\
\text { re for non-secta }\end{array}$ & $\begin{array}{l}* p<0.01, * * p<0 . \\
\text { reent" is defined } \\
\text { oarties below } 0.2 \text {. }\end{array}$ & $\begin{array}{l}\mathrm{p}<0.1 \text {. Depend } \\
\mathrm{n} \text { average seat } \mathrm{s} \\
\text { er bandwidths a }\end{array}$ & $\begin{array}{l}\text { ariable is casual } \\
\text { for protestant } p \\
\text { fined analogous }\end{array}$ & $\begin{array}{l}\text { aused by republic } \\
\text { within a range }\end{array}$ & $\begin{array}{l}\text { paramilitary } \\
00.7(0.5-0.2 \text { to }\end{array}$ \\
\hline
\end{tabular}

Table A15. Explaining casualties killed by republican paramilitaries 


\begin{tabular}{|c|c|c|c|c|c|c|}
\hline & $(1)$ & $(2)$ & (3) & (4) & $(5)$ & (6) \\
\hline & $\begin{array}{c}\text { districts with a } \\
\text { bandwidth of } 20 \\
\text { percent }\end{array}$ & $\begin{array}{c}\text { districts with a } \\
\text { bandwidth of } 15 \\
\text { percent }\end{array}$ & $\begin{array}{l}\text { districts with a } \\
\text { bandwidth of } 10 \\
\text { percent }\end{array}$ & $\begin{array}{l}\text { districts with a } \\
\text { bandwidth of } 20 \\
\text { percent }\end{array}$ & $\begin{array}{c}\text { districts with a } \\
\text { bandwidth of } 15 \\
\text { percent }\end{array}$ & $\begin{array}{c}\text { districts with a } \\
\text { bandwidth of } 10 \\
\text { percent }\end{array}$ \\
\hline VARIABLES & \multicolumn{6}{|c|}{ casualties per capita (killed by state forces) } \\
\hline power sharing & $\begin{array}{l}-0.0122^{* *} \\
(0.00477)\end{array}$ & $\begin{array}{l}-0.0123^{* *} \\
(0.00606)\end{array}$ & $\begin{array}{l}-0.00838 \\
(0.00746)\end{array}$ & $\begin{array}{l}-0.0126^{* *} \\
(0.00556)\end{array}$ & $\begin{array}{c}-0.0119 \\
(0.00768)\end{array}$ & $\begin{array}{l}-0.00473 \\
(0.00958)\end{array}$ \\
\hline $\begin{array}{l}\text { seat share of catholic } \\
\text { parties }\end{array}$ & & & & $\begin{array}{l}-0.0144 \\
(0.0210)\end{array}$ & $\begin{array}{l}-0.0104 \\
(0.0241)\end{array}$ & $\begin{array}{c}0.0215 \\
(0.0345)\end{array}$ \\
\hline $\begin{array}{l}\text { seat share of } \\
\text { protestant parties }\end{array}$ & & & & $\begin{array}{l}-0.00428 \\
(0.0233)\end{array}$ & $\begin{array}{l}0.00361 \\
(0.0259)\end{array}$ & $\begin{array}{c}0.0310 \\
(0.0351)\end{array}$ \\
\hline district fixed effects & yes & yes & yes & yes & yes & yes \\
\hline time fixed effects & yes & yes & yes & yes & yes & yes \\
\hline observations & 286 & 267 & 173 & 286 & 267 & 173 \\
\hline R-squared & 0.223 & 0.229 & 0.379 & 0.221 & 0.233 & 0.392 \\
\hline
\end{tabular}

Table A16. Explaining casualties killed by state forces 